\title{
TERRITORIALIDAD REGIA Y SISTEMAS CONCEJILES EN LA ZONA DE MONTES DE OCA Y RIOJA ALTA (SIGLOS XI AL XIV): DE LOS ALFOCES AL REALENGO CONCEJIL DE LAS VILLAS
}

\author{
José M. Monsalvo Antón \\ Universidad de Salamanca
}

En todo Occidente los siglos XII y XIII fueron una época marcada por el crecimiento económico, las mejoras en la productividad rural, la ampliación de los cultivos, el aumento de los excedentes comercializables y el incremento demográfico. Todo este telón de fondo de desarrollo estructural subyace en el aumento material de las ciudades existentes y en el nacimiento de nuevas villas y centros urbanos menores. Cada región, cada zona, tuvo peculiaridades y modulaciones específicas que afectaron a la cronología, la intensidad y la naturaleza del despliegue urbano resultante. Los territorios comprendidos entre el Duero y el Ebro conocieron también este impulso general y asimismo las peculiaridades pertinentes.

Pero además de estas cuestiones ligadas al desarrollo de lo urbano como consecuencia de ciclos generales, algo que no abordaré aquí, hay que tener en cuenta las formas de organización del territorio y los poderes, sobre todo la monarquía, para entender cómo se concretó en la zona la creación del tejido de villas y concejos, pues éste fue un efecto del crecimiento urbano pero también algo ligado y determinado por las estructuras de poder. El ámbito de estudio se corresponde con la llamada "merindad menor" de Rioja, o Rioja-Montes de Oca. Cuando en 1352 se redacta el Libro Becerro de las Behetrías esta merindad menor, que se suele sugerir como una demarcación única, sería una de las 19 merindades menores que formaban la Ilamada Merindad Mayor de Castilla',

1. La Merindad Mayor de Castilla, que por el norte llegaba al Cantábrico, limitaba al oeste con el Reino de León, al este con Navarra y al sur con la Extremadura castellana. En 1352 estaba integrada por 19 merindades menores. En 15 de ellas se llevó a cabo -y además quedó 
concretamente una de las que no se describen en el Becerro ${ }^{2}$, si bien la cifra misma de merindades menores es incluso dudosa, dada la ausencia de referencias, incluso indirectas, acerca de las áreas cuyos lugares no aparecen en la fuente ${ }^{3}$. Nuestro interés aquí no radica en estudiar la merindad o merindades menores como tales, es decir, el espacio de Montes de Oca-Rioja y su posible organización administrativa, sino tomarlo como ámbito geográfico de estudio ${ }^{4}$. Como tal, integraría tanto la Ilamada "Rioja Burgalesa", o comarcas de los Montes y el río Oca, como la parte occidental de la actual provincia de La Rioja, o Rioja Alta, con las cuencas del río Tirón, el río Oja y el río Najerilla y, de norte a sur, desde el Ebro hasta la Sierra de la Demanda.

constancia del resultado- una minuciosa relación de lugares y dominios: Cerrato, Infantazgo de Valladolid, Monzón, Campos, Carrión, Villadiego, Aguilar de Campóo, Liébana y Pernía, Saldaña, Asturias de Santillana, Castrojeriz, Candemuñó, Burgos con Ubierna, Castilla Vieja, Santo Domingo de Silos . Cfr. Libro Becerro de las Behetrías (ed. G. Martínez Díez), León, Centro de Estudios e Investigación San Isidoro, 1981, 3 vols., que es la edición indiscutida y de referencia de este importantísimo códice.

2. Hay cuatro merindades menores que no se han incluido en el Libro Becerro: Bureba, Logroño, Allende Ebro -que se corresponde aproximadamente con el territorio de Álava sin la Sonsierra-y Rioja-Montes de Oca. En esta hipotética circunscripción (sigo al considerarla como tal a Gonzalo Martínez Díez, cfr. nota anterior) habría unos 200 lugares, de los que, descontando unos 20 despoblados, quedarían 73 de ellos en la actual provincia de Burgos, 110 en la de La Rioja actual, Libro Becerro de las Behetrías, ed. citada, p. 83.

3. De hecho, G. Martínez Díez, el editor del Libro Becerro de las Behetrías (cfr. nota anterior) dice en otro trabajo sobre la provincia burgalesa que no eran 19 las merindades menores sino 20, diferenciando entre Montes de Oca y Rioja, MARTINEZ DIEZ, G., Pueblos y alfoces burgaleses de la repoblación, Valladolid, Junta de Castilla y León, 1987, p. 10. Dudas semejantes se extienden también a otras de las merindades menores no incluidas: los límites de la merindad menor de Bureba se desprenden fácilmente de la propia geografía del Libro Becerro; Logroño parece que se correspondería con la parte oriental de la actual provincia de La Rioja, es decir, Cameros y Rioja Baja; pero no es seguro cuál era el ámbito preciso de la merindad de Allende Ebro y qué parte más allá de Álava pudo incluir esta circunscripción. Son cuestiones de administración territorial del XIV que no vamos a tratar aquí, además de que tales distritos territoriales de ámbito subregional experimentaron en los siglos XIII y XIV cambios, singularizaciones y reagrupamientos diversos -casos de Pernía y Liébana, Ubierna y Burgos, Trasmiera en Castilla Vieja, Guipúzcoa antes de singularizarse...- que no son objeto de estas páginas.

4. No es la primera vez que abordamos esta cuestión en relación con áreas de la Castilla septentrional. Vid. MONSALVO ANTÓN, J. Ma., "La formación del sistema concejil en la zona de Burgos (siglo XI-mediados del siglo XIII), en Burgos en la Plena Edad Media. III Jornadas Burgalesas de Historia (Burgos 1991)", Burgos, 1994, pp.129-210; ID., "Los territorios de las villas reales de la Vieja Castilla, ss. XI-XIV: antecedentes, génesis y evolución (Estudio a partir de una docena de sistemas concejiles entre el Arlanza y el Alto Ebro)", Studia Historica. Historia Medieval, $\mathrm{n}^{\circ}$ 17, 1999, pp. 15-86. Las páginas presentes, que responden a la amable invitación de F. J. Goicolea para el número que coordina en Brocar, no pueden ser sino complemento y nueva reflexión o concreción sobre una temática ya abordada hace años en ambos trabajos citados. 
Lamentablemente, como decimos, es un importante espacio que no aparece descrito en el Libro Becerro, por causas desconocidas. Ello impide conocer con detalle y precisión no sólo la relación de lugares y dominios ${ }^{5}$ y, dentro de ella, de los centros principales y sistemas concejiles que había entonces. Tal tipo de información habría facilitado enormemente la indagación retrospectiva hacia los siglos anteriores, hasta los siglos XI o XII, que es cuando comenzaron a desplegarse nuevos poderes concejiles dentro de espacios realengos ya estructurados ${ }^{6}$. A pesar de este déficit, los datos existentes sobre esta zona de más de $2.300 \mathrm{~km}^{2}$, pese a su naturaleza y origen ${ }^{7}$, parecen suficientemente relevantes para poder trazar las grandes líneas del proceso ${ }^{8}$. Máxime cuando contamos con otra ventaja adicional de corte profesional: la larga tradición de buenos estudios sobre el medievo riojano. Esta tradición científica, al menos desde los seminales trabajos de García de Cortázar, que ha continuado luego en otros logros de él mismo, de sus discípulos y de otros historiadores, es garantía de tránsito tranquilo por estas cuestiones para cualquier historiador. $\mathrm{O}$ al menos lo

5. El estudio cumbre sobre las behetrías castellanas ha sido realizado recientemente por ESTEPA DíEZ, C., Las behetrías castellanas, Valladolid, Junta de Castilla y León, 2003, 2 vols.

6. Desde este punto de vista ya utilizamos esta información del Libro Becerro para toda la zona de Burgos e incluso, en el último trabajo citado (vid. supra, nota 4), incluyendo también referencias a los núcleos riojanos occidentales.

7. Las principales fuentes documentales son las de los monasterios de la zona. Pero son desiguales. La llamada Rioja burgalesa cuenta con referencias en las grandes colecciones de fuentes de la actual provincia, pero es una de las zonas peor documentadas de la misma. Y en cuanto al área riojana dentro de la zona de estudio, hay que decir que es la parte con mejor documentación de toda la de la actual provincia. De hecho de los 700 documentos de la actual Rioja fechados entre 923 y 1125 el 80\% pertenecen a la Rioja Alta. El dato en GARCÍA DE CORTÁZAR, J. A., "La organización social del espacio en la Rioja cristiana en los siglos X y XI", en Historia de la ciudad de Logroño. II. Edad Media (coord. J.A. Sesma), Logroño, 1995, pp. 53 168, p. 57.

8. Sin duda las fuentes principales son los fueros, alguna documentación municipal, si bien poco útil antes del siglo XIV, y las colecciones documentales de los grandes monasterios de la zona. Las fuentes que más utilizaremos aquí son las siguientes: MARTINEZ DIEZ, G., "Fueros de La Rioja", AHDE, 49, 1979, pp. 327-454 ("Fueros de la Rioja", ed. Martínez Díez); ID., Fueros locales en el territorio de la provincia de Burgos, Burgos, 1982; Cartulario de San Millán de la Cogolla (759-1076), ed. UBIETO ARTETA, A., Valencia, Anubar, 1976 (=San Millán, 759-1076, ed. Ubieto); Cartulario de San Millán de la Cogolla (1076-1200), ed. LEDESMA RUBIO, M. L., Zaragoza, Anubar, 1989 (=San Millán, 1076-1200, ed. Mª. L. Ledesma); Cartularios de Santo Domingo de la Calzada, ed. UBIETO ARTETA, A., Zaragoza, Anubar, 1978 (=Sto. Domingo Calzada, ed. Ubieto); Colección Diplomática Medieval de La Rioja. II. Documentos (923-1168), III Documentos (1168-1225), IV. Documentos del siglo XIII, ed. RODRIGUEZ DE LAMA, E. Instituto de Estudios Riojanos, Logroño, 1976-1979, 1989, 4 vols. (reed. 1992) (=CDM Rioja, ed. Rodríguez de Lama); Colección documental de Santa María la Real de Nájera (siglos X-XIV), ed. CANTERA MONTENEGRO, M., San Sebastián, 1991 (= Santa Ma ${ }^{a}$ Nájera, ed. M. Cantera); Documentación medieval del Monasterio de Valvanera (siglos XI al XIII), ed. GARCIA TURZA, J., Zaragoza, 1989 (=Valvanera, ed. García Turza). 
es para alguien, como es mí caso, interesado por el origen de los concejos, pero más centrado normalmente en el espacio geográfico castellano-leonés.

\section{La vieja territorialidad del "realengo directo»: alfoces y tenencias}

El territorio objeto de estudio estuvo en los siglos X-XII a caballo entre los reinos de Castilla y de Pamplona, o "Nájera y Pamplona", como era denominado este último reino hasta 1076. En el reinado de Sancho III el Mayor, concretamente en 1016, se llevó a cabo una delimitación fronteriza9 ${ }^{9}$ que a grandes rasgos reflejaba bien el protagonismo de castellanos y pamploneses en la repoblación del siglo X. En líneas generales, la cuenca alta del Arlanzón, el Río Tirón, el Río Oja y la Sierra de la Demanda quedaron en manos del entonces Condado de Castilla; la cuenca del Najerilla al este y la Sierra de Cameros serían de Pamplona.

Después hubo vicisitudes, bien conocidas, en la historia política y en las fronteras, que naturalmente afectaron a la zona: ventajas para Pamplona en 1035, con la inclusión en su reino, bajo García III, de la importante Castilla Vetula y Bureba; recuperación de ambos espacios por Castilla y ampliación por Fernando I tras vencer a su hermano, el rey de Pamplona y Nájera, en 1054, donde pereció este último monarca ${ }^{10}$; nuevo desastre navarro en Peñalén en 1076, con la muerte de Sancho IV de Pamplona, la desaparición momentánea del reino y su reparto entre Castilla, que se quedó con las tierras riojanas, alavesas y vizcaínas, y Aragón, que se hizo con el área pamplonesa-navarra; adscripción luego de toda la actual Rioja a los dominios de Alfonso VI de Castilla y León, entre 1076 y la muerte del rey castellanoleonés, en 1109, que es justo el período en que se dieron los primeros grandes fueros riojanos, Nájera y Logroño; más tarde, tras resistir la presión de Alfonso el Batallador de Aragón en la frontera con Castilla, consolidación definitiva con Alfonso VII, entre 11231157, de todos aquellos territorios que, andando el tiempo, se supone que formaron la citada merindad menor de Rioja.

Estos vaivenes no cuestionaron lo que desde el siglo XI, sin duda con antecedentes en el siglo anterior, constituía la forma axial de organización territorial característica: las tenencias. Las tenencias eran la expresión del poder regio en un determinado territorio. Tradicionalmente su origen se situaba en el reino de

9. Hay una escueta concordia y convenientia sobre límites entre Sancho Garcés III y Sancho García de Castilla en 1016, San Millán, 759-1076, ed. Ubieto, doc. 166.

10. Este monarca es conocido como "el de Nájera". Hace unos años la Semana de Estudios Medievales de Nájera le dedicó las sesiones. Vid. las actas en García Sánchez III "el de Nájera": un rey y un reino en la Europa del siglo XI, Logroño, XV Semana de Estudios Medievales, 2005. A destacar en relación con la figura los trabajos allí presentados por Á. Martín Duque, M. Cantera y E. Ramírez Vaquero. 
Pamplona y Aragón ${ }^{11}$ y, según se suponía, habría pasado luego a Castilla. Es un tópico difusionista que hace tiempo viene desmentido por la observación de los alfoces y castillos regios en la Castilla condal y en León en los siglos X y XI.

No obstante la cuestión de los alfoces es controvertida en otros aspectos. En una visión tradicional se entiende que eran distritos regios uniformes desplegados desde arriba y con semejantes bases jurídicas para administrar los intereses del rey. Estos distritos se Ilamarían preferentemente alfoces y en el XI derivarían en tenencias. Esta interpretación institucionalista resalta sobre todo estos rasgos de distritos netos, dirigidos desde los castillos regios, instituidos para administrar el territorio y sometidos a una secuencia histórica afín, es decir, el citado paso del alfoz a la tenencia, y a un esquema jerárquico y administrativo rígido: rey/conde/tenente ${ }^{12}$. Pero hay enfoques diferentes.

Desde otro punto de vista, los alfoces tendrían orígenes distintos: comunidades de valle en algunos casos, aglutinación en torno al prestigio de una civitas otras veces, simples denominaciones de comarcas naturales sin un castillo central como nódulo único o también, por qué no, creaciones nuevas y deliberadas desde la monarquía. De modo que la situación sería más variada y menos administrativa de lo que parece. Desde esta perspectiva, contrapuesta a la jurídico-institucionalista y pese a no ser tampoco unívoca, se entiende que muchos alfoces bien podrían tener un origen remoto, aunque es cierto que a lo largo de los siglos X-XI la adaptación a la horma de las exigencias de la monarquía

11. Es clásico el estudio de LACARRA, J. $\mathrm{M}^{\mathrm{a}}$., "Honores y tenencias en Aragón. Siglo XI", CHE, 45-46, 1967, pp. 151-190.

12. Quizá es el libro de Martínez Díez sobre los alfoces burgaleses el más característico, MARTÍNEZ DIEZ, G. Pueblos y alfoces de la repoblación, Valladolid, Junta Castilla y León, 1987. La etimología de alfoz a partir del término árabe que significa "distrito" o "cantón", que Martínez Díez señala, según este punto de vista se correspondería con la función de circunscripciones desarrolladas desde arriba por el poder central -aunque sea éste el de los Condes de CastiIla- para gobernar los territorios, Pueblos y alfoces, p. 10. Ahora bien, el libro de Martínez Díez más que un estudio dinámico del territorio es un trabajo de cartografía descriptiva de lugares de la provincia de Burgos del Ebro al sur, ubicados en sus respectivos distritos. Se incluyen todos los lugares que hay o hubo en cada zona. Esto es irreal. Además de que no se tienen en cuenta los cambios y las diferencias geográficas, en mi opinión se olvida que muchos de los lugares incluidos en algún momento no podían pertenecer al ningún alfoz regio, ya que éste sólo afectaba a los lugares de realengo. Este desajuste grave, que hace ficticia la geografía de alfoces que presenta el insigne historiador de Quintanar de la Sierra, deriva del hecho de considerar los alfoces como "distritos" convencionales -como lo serían hoy una provincia o un partido judicialolvidando que en esa época el poder no operaba así, sino que había varios niveles y ausencia de homogeneidad jurisdiccional y territorial. No obstante, como geografía del poblamiento medieval, en su sentido de inventario estático, el libro tiene interés. Hay que decir que el libro de Martínez Díez no fue para la zona burgalesa el primer intento de dar a conocer con detalle los alfoces. Mucho antes se escribió otro trabajo de corte tradicional: LOPEZ MATA, Geografía del condado de Castilla a la muerte de Fernán González, Madrid, 1957. También estudió exhaustivamente el alfoz de Burgos. 
-reyes de León, en León, Condes y luego reyes de Castilla- algunos entendemos que sí pudo haber operado en un sentido unificador. De este modo, suave y paulatinamente, los alfoces habrían tendido a funcionar como «tenencias» regias. Ahora bien, no hay una correlación de uno a una, sino que, en ocasiones, una tenencia absorbió varios alfoces -al norte del Duero esto fue frecuente- o relanzó un determinado castillo regio que supuso el declive de otros centros, o hizo llevar un mínimo aparato estatal a una comarca en la que antes no lo había... No hay una regla fija, pero en general pensamos que el mapa de tenencias de los siglos XI y XII supuso una cierta simplificación, selección y mayor semejanza de centros respecto al del siglo $X$, más heterogéneo y con mayor número de territorios identificados.

Esta visión más abierta sobre la pluralidad de orígenes de los alfoces es la que hemos utilizado en nuestros trabajos. Y creo que se ajusta mejor a los estudios monográficos que se han hecho sobre ciertas zonas. A mi juicio, esta segunda perspectiva es más enriquecedora ${ }^{13}$, ya que contempla: los problemas de las relaciones sociales, esto es, la cuestión de las sociedades gentilicias, comunidades de aldea y otras; las formas de organización del espacio, esto es,

13. Creo que el trabajo seminal de esta perspectiva fue el de ESTEPA DIEZ, C., "El alfoz castellano en los siglos IX al XII", En la España Medieval, IV, 1984, pp. 305-341. Vid. además GARCIA DE CORTÁZAR, J.A., PEÑA BOCOS, E., "De alfoces, aldeas y solares en la Castilla de los siglos IX a XI, ¿Una formalización feudal del espacio?", en Miscel.lánea en Homenatge al prof. Agustín Altisent, Tarragona, 1991, pp. 183-202, además de otros trabajos de García de Cortázar que se mencionan en estas páginas; ALVAREZ BORGE, I., Poder y relaciones sociales en Castilla en la Edad Media. Los territorios entre el Arlanzón y el Duero en los siglos $X$ al XV, Salamanca, 1996; ID., Monarquía feudal y organización territorial. Alfoces y merindades en Castilla (siglos X-XIV), Madrid, 1993, entre otros trabajos del autor, que ha tratado en sus importantes estudios campesinado, señorialización y estructuras territoriales de la monarquía; JULAR, C. "Alfoz y tierra a través de documentación castellana y leonesa de 1157 a 1230. Contribución al estudio del dominio señorial", Studia Historica. Historia Medieval, 9, (1991), pp. 9-42; ESCALONA MONGE, J., "Algunos problemas relativos a la génesis de las estructuras territoriales de la Castilla altomedieval", en II Jornadas Burgalesas de Historia. Burgos en la Alta Edad Media, Burgos, 1991, pp. 489-506; ID., Sociedad y Territorio en la Alta Edad Media Castellana. La Formación del Alfoz de Lara, Oxford, 2002, entre otros trabajos de este autor, uno de los que ha aportado recientes e innovadoras perspectivas sobre los territorios regios; de otro autor especializado, PASTOR DÍAZ DE GARAYO, E., vid. su libro Castilla en el tránsito de la Antigüedad al Feudalismo. Poblamiento, poder político y estructura social del Arlanza al Duero (siglos VII-XI), Valladolid, 1996; asimismo, MARTíN VISO, I., Poblamiento y estructuras sociales en el norte de la Península Ibérica, siglos VI-XIII, Salamanca, Universidad, 2000; ID., "Territorios, poder feudal y comunidades en la Castilla septentrional (siglos XIXIV)". Edad Media. Revista de Historia, 5, 2002, pp. 217-263, entre otros trabajos de este autor, otro de los mayores especialistas en la temática y buen conocedor de la zona; PEÑA BOCOS, E., "Alfoces y tenencias: La Rioja", en J. A. García de Cortázar (ed.), Del Cantábrico al Duero. Trece estudios sobre organización social del espacio en los siglos VIII a XIII, Santander, 1999, pp. 375-411. Vid. asimismo las consideraciones que hacemos en los trabajos citados en nota 4. 
comunidades de valle, aldeanización, poblamientos supraaldeanos en altura, entre otras; la existencia de discontinuidades geográficas y de áreas y gentes no sometidas o condicionadas por las mismas formas de control; y la modulación histórica de los medios y recursos del poder político para penetrar en el tejido social, que incluyen por ejemplo problemas como la cuestión de las crisis de los poderes públicos, las reconstrucciones de la influencia y la autoridad de los poderes condales o regios, sus conexiones con las elites rurales, las cargas y rentas o las dificultades de la recaudación, entre otras cuestiones que exceden totalmente una mera óptica jurídica acerca de la administración territorial. En el fondo, la interpretación institucionalista tiende a adoptar de algún modo el punto de vista de quien gobierna -que, dicho sea de paso, suele ser un punto de vista certero para entender muchas realidades del poder-, y hablan de distritos y delegaciones formales. Mientras que el segundo enfoque se fija más en los espacios sociales de los gobernados y en la historicidad de sus ámbitos de encuadramiento.

Hechas estas, digamos, aclaraciones conceptuales nos preguntamos cómo se concreta en la zona de estudio esta cuestión de los alfoces y tenencias. Desde luego, las principales fuentes para acercarnos a esta realidad son las colecciones documentales de los monasterios de la zona, como hemos indicado ${ }^{14}$. Ciertas aglomeraciones no ofrecen duda sobre su papel como centros territoriales. Es el caso de Nájera, que fue recuperada por los cristianos en el 923. La civitas $^{15}$ de Nájera fue el núcleo de más rango de la zona en términos históricos. Pasó de ser segunda corte con Sancho III el Mayor a primera con García Sánchez III y Sancho Garcés IV. Entre 1035 y 1076 estos reyes de Pamplona se Ilaman también, y los diplomas así lo corroboran, reyes de Nájera o "de Pamplona y Nájera"16. No podía haber mayor preeminencia para una urbe. No obstante, por debajo de esta máxima condición de urbs regia, hubo también su correspondiente tenente en Nájera en ese período. Luego en manos castellanas fue una importante tenencia, pero Alfonso VI situó por encima del tenente propiamente dicho al comite García Ordóñez. Alfonso VI reconocía el papel simbólico de Nájera y en su Fuero de 1076 daba un estatuto con contenido político para una civitas sobresaliente. Pero a la vez era consciente de que el fuero debía regular la vida urbana. Inmediatamente me referiré a ello. En cualquier caso, Nájera puede considerarse una de las tenencias clave y de largo recorrido histórico.

14. Vid. títulos citados en nota 8. Asimismo el ANEXO que presentamos, referido sólo a los siglos X y XI.

15. Así es denominada en un documento de 957, San Millán, 759-1076, ed. Ubieto, doc. 76.

16. Se puede ver en las colecciones documentales profusamente. Sigue apareciendo la denominación de civitas, San Millán, 759-1076, ed. Ubieto, doc. 310, de 1060. 
En otros casos el origen de los alfoces se detecta también en fechas tempranas. Se habla tanto de territorium como de alfoz. Por ejemplo, Oca es mencionada, como alfoz, en el $964^{17}$. Pero ya antes, en el 947, se menciona un lugar, Fenestra, que se hallaría "in territorio de Auca"18. Es evidente que Oca poseía una jerarquía. ¿De donde nacía? En este caso, parece que la mención a la realidad de Oca como civitas estaría en la base. Un documento del cartulario de San Millán sobre derechos de pasto menciona el enclave de la civitate aukense como referencia, así como los montes aukensi. La mención ${ }^{19}$ puede sugerirnos que un núcleo, de origen prefeudal, en el que se sustentó la civitas de Oca, podría haber dado lugar a un centro que, Ilegado un momento, sirvió para desplegar un alfoz regio. La condición de sede episcopa ${ }^{20}$ en los siglos X y XI -hasta el traslado a Burgos en $1075^{21}$ - habría robustecido sin duda su distinción como centro territorial. Tanto es así que fue considerado muy importante por los pamploneses tras Sancho el Mayor ${ }^{22}$, cuando esta parte del Condado de Castilla quedó por su herencia del lado pamplonés.

17. Becerro Gótico de Cardeña, ed. L. Serrano, Valladolid, 1910, doc. 363.

18. San Millán, 759-1076, ed. Ubieto, doc. 46. Era una fundación monástica hecha por el abad Salitus.

19. El documento parece fechado en 869, San Millán, 759-1076, ed. Ubieto, doc. 9. Seguramente la fecha es falsa, pero ello no afecta a lo que decimos.

20. MARTíNEZ DíEZ, G., "Los obispados de la Castilla condal hasta la consolidación del obispado de Oca en el concilio de Husillos", El factor religioso en la formación de Castilla (Symposium, 1984), Burgos, 1984, pp. 87-164; asimismo MARTíN VISO, I., "Organización episcopal y poder entre la Antigüedad Tardía y el Medievo (siglos V-XI): las sedes de Calahorra, Oca y Osma", Iberia, 2, 1999, pp. 151-190.

21. Documentación de la Catedral de Burgos (804-1183), ed. Garrido Garrido, J.M., Burgos, 1983, docs. 27-29.

22. El escatocolo de un documento del monasterio de Valvanera dice "regnante Domino nostro Ihesu Christo; sub eius imperio, rex Garsea in Pampilona et in Oka", Valvanera, ed. García Turza, doc. 2. La expresión se repite en documentos de 1037, 1047, 1052, etc., Valvanera, ed. García Turza, doc. 4, 6, 14, 17, 18. La importancia de citar en los diplomas a Oca como gran referencia de los dominios regios de García de Navarra se comprueba al ver que se sitúa al mismo nivel que las grandes demarcaciones castellanas sobre las que en esos años regía el rey de Pamplona, es decir Castilla Vieja, Álava y Bureba. Basta citar tan sólo, a modo de muestra, varias referencias de la documentación de ese monasterio citado durante el reinado indicado: así, en otro documento de 1037, con la misma finalidad de subrayar los dominios del monarca pamplonés, se alude a Castilla Vieja, otra parte clave que quedó para Pamplona tras 1035: "Garsea, rex in Pampilona et in Castiella Vetula", Valvanera, ed. García Turza, doc. 5. Castilla Vetula se sigue citando en 1052 como pieza clave de los dominios del rey García, Ibid.,doc. 19. Lo mismo se subraya con respecto a Bureba (Ibid., doc. 3, de 1035, o doc. 8, de 1042, o doc. 13, de 1047, o doc. 19 de 1052) y a Alava (ibid. doc. 7, de 1042, o doc. 12, de 1046, o doc. 16, de 1050, o doc. 19 de 1052, o docs. 20, 21,22 de 1053, o doc. 24 de 1054). Es decir, Oca es cita$\mathrm{da}$, al igual que Bureba, Alava y Castilla Vieja, como una de las piezas que, junto al reino patrimonial de Pamplona-Nájera, formaban los dominios de García Sánchez III. 


\section{ANEXO. Centros territoriales regios (siglos X-XI)}

\begin{tabular}{|c|c|c|}
\hline Centro territorial & Año & Referencia documental a los territorios y delegados regios (siglos X-XI) \\
\hline Anguiano & 1073 & "Sancio Gartiaç in Tobia et in Anguidanos", Valvanera, ed. García Turza, doc. 66 \\
\hline \multirow[t]{4}{*}{ Azofra $^{23}$} & 1040 & $\begin{array}{l}\text { [Donación hecha por García III, rey de Nájera, a su esposa Estefanía]: "senior } \\
\text { Azenari Furtunionis de Zafra" CDM Rioja, ed. Rodríguez de Lama, doc. } 3\end{array}$ \\
\hline & 1044 & $\begin{array}{l}\text { "senior Azenarii Fortunionis de Azafra", CDM Rioja, ed. Rodríguez de Lama, } \\
\text { doc. 4; Santa Ma. Nájera, ed. M. Cantera, doc. } 7 .\end{array}$ \\
\hline & 1046 & $\begin{array}{l}\text { "senior Eximino Garzeiz de Azafra", CDM Rioja, ed. Rodríguez de Lama, doc. 8; } \\
\text { "senior Eximino Garzeiz de Azofra", Santa Ma. Nájera, ed. M. Cantera Santa Ma. } \\
\text { Nájera, ed. M. Cantera, doc. } 8 .\end{array}$ \\
\hline & 1081 & $\begin{array}{l}\text { "Petro lohannes dominante Nagela siue Azofra", CDM Rioja, ed. Rodríguez de } \\
\text { Lama, doc. } 37 .\end{array}$ \\
\hline \multirow[t]{5}{*}{ Cañas } & 1046 & $\begin{array}{l}\text { "regnante rex Garsea in Pampilonia et in Oka; et sub eius, Mohomade[?] domi- } \\
\text { nans in Kannas", Valvanera, ed. García Turza, doc. } 11 .\end{array}$ \\
\hline & 1066 & "Furtun Scemenionis dominans in Kannas", Valvanera, ed. García Turza, doc. 34. \\
\hline & 1066 & "Ieneco Sançio, potestate in Kannas", Valvanera, ed. García Turza, doc. 36. \\
\hline & 1067 & "Furtun Scemenionis in Kannas", Valvanera, ed. García Turza, doc. 39. \\
\hline & 1969 & $\begin{array}{l}\text { "in Kannas, senior Furtun Scemenonis", Valvanera, ed. García Turza, doc. 48; } \\
\text { ibid., 51, 52. }\end{array}$ \\
\hline \multirow[t]{9}{*}{ Cerezo } & 913 & $\begin{array}{l}\text { "Comite Gundisalvo Telliz in Cerasio", Becerro Gótico de Cardeña, ed. L. Serra- } \\
\text { no, Valladolid, 1910, doc. } 322 .\end{array}$ \\
\hline & 936 & $\begin{array}{l}\text { "Dolquiti Beilaz, dum esse iudicen in Cereso (...) regnante Regimito in Legione et } \\
\text { comite Fredinando in Cereso et in Granione", San Millán, 759-1076, ed. Ubieto, } \\
\text { doc. } 23 .\end{array}$ \\
\hline & 938 & $\begin{array}{l}\text { "Fredinando nutu Dei comes tenentem Castellam et Cereso et Granionem", San } \\
\text { Millán, 759-1076, ed. Ubieto, doc. } 26 .\end{array}$ \\
\hline & 970 & $\begin{array}{l}\text { Se cita un pequeño monasterio junto al río Tirón, "sub territorio" de Cerezo, Car- } \\
\text { tulario de San Pedro de Arlanza, ed. L. Serrano., Madrid, } 1925 \text { doc. 21; Col. } \\
\text { Diplom. Condes de Castilla, ed. Zabalza, doc. } 36 .\end{array}$ \\
\hline & 978 & $\begin{array}{l}\text { "de Cerasio..." [posesiones de Covarrubias en ese alfoz]", Covarrubias, ed. Serra- } \\
\text { no, docs. } 7 \text { y 8; Doc. Catedral Burgos, ed. Garrido, doc. 9; Col. Diplom. Condes } \\
\text { de Castilla, ed. Zabalza, docs. } 52 \text { y } 53 .\end{array}$ \\
\hline & 1068 & $\begin{array}{l}\text { "in alhoz de Cereso", Documentación de la Catedral de Burgos (804-1183), ed. } \\
\text { Garrido Garrido, J.M., Burgos, 1983, doc. } 20 .\end{array}$ \\
\hline & 1073 & $\begin{array}{l}\text { "dominans in Cereso, senior Peitro Morielleç", Valvanera, ed. García Turza, doc. } \\
68 .\end{array}$ \\
\hline & 1075 & $\begin{array}{l}\text { "dominans in Cereso, Pedro lohannes; et sub ille, Domingo lohannes", Valvane- } \\
\text { ra, ed. García Turza, doc. } 72 .\end{array}$ \\
\hline & 1077 & $\begin{array}{l}\text { "Martin Sanchiz merino in Burgis et in Cereso", San Millán, 1076-1200, ed. } \\
\text { M.L. Ledesma, doc. } 4 .\end{array}$ \\
\hline
\end{tabular}

23. No es seguro que en alguno de los casos no se trate de Azagra y no Azofra. 


\begin{tabular}{|c|c|c|}
\hline Centro territorial & Año & Referencia documental a los territorios y delegados regios (siglos X-XI) \\
\hline & 1078 & $\begin{array}{l}\text { "et in Cereso senior Martin Sangoz; et sub ille merino don Gomice", Valvanera, } \\
\text { ed. García Turza, doc.102. }\end{array}$ \\
\hline & 1081 & $\begin{array}{l}\text { "et merino in Cereso Martin Sanchez", San Millán, 1076-1200, ed. Ma.L. Ledes- } \\
\text { ma, doc. } 35 .\end{array}$ \\
\hline & 1082 & $\begin{array}{l}\text { "sennor Martini Sanchiz, merino in Burgis et Cereso", San Millán, 1076-1200, } \\
\text { ed. Ma.L. Ledesma, doc. } 57 .\end{array}$ \\
\hline & 1089 & $\begin{array}{l}\text { "dominans in Cereso senior Petro lohannes, et sub ille, Domingo lohannes", Val- } \\
\text { vanera, ed. García Turza, doc. } 188 .\end{array}$ \\
\hline & 1090 & $\begin{array}{l}\text { "comite Gomessano in Cereso et in Ponticurbo et in Petralata", San Millán, 1076- } \\
\text { 1200, ed. Ma.L. Ledesma, doc. } 201 .\end{array}$ \\
\hline & 1092 & $\begin{array}{l}\text { "regnante rex Addefonso in Toleto et in Tota Spania; et sub eius imperio, domi- } \\
\text { nans Cereso Tel Didaz; et sub ille, Dominico lohannes", Valvanera, ed. García } \\
\text { Turza, doc. } 191 .\end{array}$ \\
\hline & 1095 & $\begin{array}{l}\text { "sennor Dominico lohanne, merino in Cereso", San Millán, 1076-1200, ed. Ma.L. } \\
\text { Ledesma, doc. } 255 .\end{array}$ \\
\hline & 1099 & $\begin{array}{l}\text { "comite don Gomez in Cereso et in Borovia", San Millán, 1076-1200, ed. Ma.L. } \\
\text { Ledesma, doc. } 278 .\end{array}$ \\
\hline \multirow[t]{12}{*}{ Grañón } & 936 & $\begin{array}{l}\text { "Dolquiti Beilaz, dum esse iudicen in Cereso (...) regnante Regimiro in Legione et } \\
\text { comite Fredinando in Cereso et in Granione", San Millán, 759-1076, ed. Ubieto, } \\
\text { doc. } 23 .\end{array}$ \\
\hline & 938 & $\begin{array}{l}\text { "Fredinando nutu Dei comes tenentem Castellam et Cereso et Granionem", San } \\
\text { Millán, 759-1076, ed. Ubieto, doc. } 26 .\end{array}$ \\
\hline & 1040 & $\begin{array}{l}\text { [carta de arras de García de Nájera a Estefanía de Foix]: “...et Granione cum tota } \\
\text { sua mandatione", CDM Rioja, ed. Rodríguez de Lama, doc. } 3 .\end{array}$ \\
\hline & 1052 & $\begin{array}{l}\text { [Donación hecha por García III, rey de Nájera, y su esposa Estefanía]: "totas } \\
\text { meas hereditates, quas laborauerint in Granione et sua alfoce" CDM Rioja, ed. } \\
\text { Rodríguez de Lama, doc. } 12 .\end{array}$ \\
\hline & 1069 & $\begin{array}{l}\text { [donación del monasterio de Santo Tomé de Grañón a San Millán] "in confinio } \\
\text { castro Grannioni", San Millán, 759-1076, ed. Ubieto, doc. } 376 .\end{array}$ \\
\hline & 1073 & $\begin{array}{l}\text { "regnante rex Santio in Nagera; et in Graione, Vermudo Gutierrez", Valvanera, } \\
\text { ed. García Turza, doc.64. }\end{array}$ \\
\hline & 1074 & $\begin{array}{l}\text { "senior Bermud Guterrez de Grannon", Santa Ma. Nájera, ed. M. Cantera, doc. } \\
19 .\end{array}$ \\
\hline & 1081 & $\begin{array}{l}\text { "senior Bermud Gutierrez in Granione", San Millán, 1076-1200, ed. Ma.L. Ledes- } \\
\text { ma, doc. } 35 .\end{array}$ \\
\hline & 1084 & $\begin{array}{l}\text { "sennor Alvaro Didaz dominantur Granione", San Millán, 1076-1200, ed. Mª.L. } \\
\text { Ledesma, doc. } 76 .\end{array}$ \\
\hline & 1085 & "sennor Alvaro Didaz", San Millán, 1076-1200, ed. Mª. L. Ledesma, doc. 103. \\
\hline & 1089 & $\begin{array}{l}\text { "comite don Garsea [Ordóñez], dominator Naiera et Grannione", San Millán, } \\
\text { 1076-1200, ed. Ma..L. Ledesma, doc. } 191 .\end{array}$ \\
\hline & 1090 & $\begin{array}{l}\text { "comite Garsea in Naiera et in Granione", San Millán, 1076-1200, ed. Ma.L. } \\
\text { Ledesma, doc. } 202 .\end{array}$ \\
\hline $\begin{array}{l}\text { Haro } \\
\text { (con Bilibio) }\end{array}$ & 1040 & $\begin{array}{l}\text { [carta de arras de García de Nájera a Estefanía de Foix]: "....senior Azenariz } \\
\text { Furtunionis, Bilibio cum Faro", CDM Rioja, ed. Rodríguez de Lama, doc. } 3 .\end{array}$ \\
\hline
\end{tabular}


TERRITORIALIDAD REGIA Y SISTEMAS CONCEJILES...

\begin{tabular}{|c|c|c|}
\hline Centro territorial & Año & Referencia documental a los territorios y delegados regios (siglos X-XI) \\
\hline \multirow[t]{4}{*}{ Ibrillos } & 1073 & $\begin{array}{l}\text { "et in Ibriellos, senior Didako Albariç et sub ille, senior Didado Gudis", Valvane- } \\
\text { ra, ed. García Turza, doc. } 68 .\end{array}$ \\
\hline & 1075 & $\begin{array}{l}\text { "et in Ibriellos, senior Didago Alvareç; et sub ille, Didago Gudistioç", Valvanera, } \\
\text { ed. García Turza, doc. } 72 .\end{array}$ \\
\hline & 1078 & $\begin{array}{l}\text { "et in Ibriellos senior Didaco Alvariz; et sub eius Didaco Gudestuz", Valvanera, } \\
\text { ed. García Turza, doc. } 102 .\end{array}$ \\
\hline & 1089 & $\begin{array}{l}\text { "et in Ibriellos dominans senior Didako Albariz et sub ille Blasko Didaz", Valva- } \\
\text { nera, ed. García Turza, doc. } 188 .\end{array}$ \\
\hline \multirow[t]{3}{*}{ Matute } & 1073 & $\begin{array}{l}\text { "domno Antonino in Matute et in Villanoba", Valvanera, ed. García Turza, doc. } \\
67 .\end{array}$ \\
\hline & 1080 & $\begin{array}{l}\text { "regnante Adfonsus rex in Spania; et senior Antonino Nunniç, dominante Matuti } \\
\text { ac Tobia", Valvanera, ed. García Turza, doc. } 133 .\end{array}$ \\
\hline & 1081 & $\begin{array}{l}\text { "Adefonsus rex in Legione et in Nagera; et sub eius, senior Antolin Nunez in } \\
\text { Tubia; discurrente iudicio alcaldi in Matute Genneco Sabastianez; et in Villanova } \\
\text { Sancio Scemeno, adenantato", Valvanera, ed. García Turza, docs. 151, 158, } 159 .\end{array}$ \\
\hline \multirow[t]{12}{*}{ Nájera } & 943 & $\begin{array}{l}\text { [el rey de Pamplona García Sánchez I hace donación del lugar de Villar de la } \\
\text { Torre o Val de la Torre a San Millán]: "villam in confinium Naiele positam, anti- } \\
\text { quo usu Villar de Torre dictam", San Millán, 759-1076, ed. Ubieto, doc. } 30 .\end{array}$ \\
\hline & 971 & $\begin{array}{l}\text { Donación a San Millán del lugar de Villagonzalo "in super urbio Naiarensi, iuxta } \\
\text { rivum Cardines", San Millán, 759-1076, ed. Ubieto, doc. } 88 .\end{array}$ \\
\hline & 1020 & $\begin{array}{l}\text { [donación a San Millán de San Cristóbal de Tobía]: "sennor Enneco Sancii in } \\
\text { Naiera testis", San Millán, 759-1076, ed. Ubieto, doc. 171; Valvanera, ed. García } \\
\text { Turza, doc. } 1 .\end{array}$ \\
\hline & 1035 & $\begin{array}{l}\text { "rex Garsea in Pampilona et in Oka; et sub eius, senior Furtun Sancioç dominans } \\
\text { in Nayara", Valvanera, ed. García Turza, doc. 2.; semejante ese mismo año Valva- } \\
\text { nera, ed. García Turza, doc. } 3 .\end{array}$ \\
\hline & 1035 & $\begin{array}{l}\text { "regnante Garsea rex in Pampilona et in Castella usque ad Zamora, sub eius } \\
\text { imperio Fortun Sanchiz in Naiera", San Millán, 759-1076, ed. Ubieto, doc. } 205 .\end{array}$ \\
\hline & 1036 & $\begin{array}{l}\text { "sennor Fortun Sanchiz dominante Naiera", San Millán, 759-1076, ed. Ubieto, } \\
\text { doc. 207; Ibid., doc. } 208 .\end{array}$ \\
\hline & 1037 & $\begin{array}{l}\text { "rex Garsea in Pampilona et in Oka; et sub eius, senior Furtun Sancioç dominans } \\
\text { in Nagara", Valvanera, ed. García Turza, doc. 4. Asimismo, ibid., docs. } 5 \text { y 6, de } \\
\text { ese año. }\end{array}$ \\
\hline & 1040 & $\begin{array}{l}\text { [carta de arras de García de Nájera a Estefanía de Foix]: "senior Fortunio Sanci } \\
\text { cum ipsa patriaque tenet, id est, Naila [Nájera] et Punicastro uel Pedra Alta, Arlas } \\
\text { et Falces et Sanguessa cum omni herentia eorum", CDM Rioja, ed. Rodríguez de } \\
\text { Lama, doc. } 3 .\end{array}$ \\
\hline & $1037-54$ & $\begin{array}{l}\text { Fortún Sancio, senior o dominans en Nájera, Valvanera, ed. García Turza, docs. } \\
\text { 7, 8, 13, 14, 16, 18,20,21,22, 24, 25, 26; San Millán, 759-1076, ed. Ubieto, } \\
\text { docs. 256, 257, 258, 269, 270, 271; CDM Rioja, ed. Rodríguez de Lama, doc. 8; } \\
\text { Santa Ma } \text {. Nájera, ed. M. Cantera, doc. } 8 \text {. }\end{array}$ \\
\hline & 1050 & $\begin{array}{l}\text { "Fortun Sancii dominator Naiera confirmans, Garsea Lifuar, milex eius, confir- } \\
\text { mans", San Millán, 759-1076, ed. Ubieto, doc. } 270 .\end{array}$ \\
\hline & 1064 & "Ienneco Lopeç in Naira", Valvanera, ed. García Turza, doc. 31. \\
\hline & 1066 & "senior Fernando Fernandiz in Naiara", Santa Ma. Nájera, ed. M. Cantera, doc. 17. \\
\hline
\end{tabular}




\begin{tabular}{|c|c|c|}
\hline Centro territorial & Año & Referencia documental a los territorios y delegados regios (siglos X-XI) \\
\hline & $1066-67$ & $\begin{array}{l}\text { "senior lenneco Lopeç, dominans in Nagera", Valvanera, ed. García Turza, docs. } \\
35,38 .\end{array}$ \\
\hline & 1067 & "lenneco Açnareç, dominans in Nagera", Valvanera, ed. García Turza, docs. 39, 40. \\
\hline & 1068-69 & Iñigo López, senior o dominans en Nájera, Valvanera, ed. García Turza, docs. 45-49. \\
\hline & 1069 & "senior Genneco Açenari in Nagera", Valvanera, ed. García Turza, doc. 40. \\
\hline & 1071 & $\begin{array}{l}\text { "senior Azenar Sanchez dominator Naierae", San Millán, 759-1076, ed. Ubieto, } \\
\text { doc. } 393 .\end{array}$ \\
\hline & $1070-75$ & $\begin{array}{l}\text { Iñigo López, comes, senior o dominans en Nájera, Valvanera, ed. García Turza, } \\
\text { docs. 54, 55, 58, 60, 61, 65, 66, 70, 71; San Millán, 759-1076, ed. Ubieto, docs. } \\
\text { 383, 418; CDM Rioja, ed. Rodríguez de Lama, docs. 27, 28, 29, 37; Santa Mª. } \\
\text { Nájera, ed. M. Cantera, doc. 19. }\end{array}$ \\
\hline & $\begin{array}{l}1075- \\
1100\end{array}$ & $\begin{array}{l}\text { Seniores o dominantes: Martin Sangoz, Pedro Juanes, Citi Petriz; y, por encima, } \\
\text { desde 1076, o a veces como única autoridad territorial citada, el comes García } \\
\text { Ordóñez (años 80): Valvanera, ed. García Turza, docs. 78, 82, 84, 94, 103, 160, 161, } \\
\text { 163, 165, 179, 183, 185, 186, 192; CDM Rioja, ed. Rodríguez de Lama, doc. 37; } \\
\text { Santa Má. Nájera, ed. M. Cantera, doc. 26; San Millán, 1076-1200, ed. Ma.L. Ledes- } \\
\text { ma, docs. 44, 55, 76, 94, 103, 107, 109, 118, 120, 139, 142, 143, 148, 165, 167, } \\
\text { 171, 172, 174, 189, 190, 191, 204, 209, 212, 214, 228, 229, 265, 264, 266, 272. }\end{array}$ \\
\hline \multirow[t]{13}{*}{ Oca } & 947 & $\begin{array}{l}\text { "in loco que vocitant Bonelli, in Fenestra, in territorio de Auca", San Millán, 759- } \\
\text { 1076, ed. Ubieto, doc. } 46 .\end{array}$ \\
\hline & 964 & $\begin{array}{l}\text { [San Julián] "baselica fundata in alfoze Auca", Becerro Gótico de Cardeña, ed. L. } \\
\text { Serrano, Valladolid, 1910, doc. 363; Col. Diplom. Condes de Castilla, ed. Zabal- } \\
\text { za, doc. } 32 \text {. }\end{array}$ \\
\hline & 978 & $\begin{array}{l}\text { "in Auka..." [posesiones de Covarrubias en ese alfoz", Covarrubias, ed. Serrano, } \\
\text { docs. } 7 \text { y 8; Doc. Catedral Burgos, ed. Garrido, doc. 9; Col. Diplom. Condes de } \\
\text { Castilla, ed. Zabalza, docs. } 52 \text { y } 53 .\end{array}$ \\
\hline & 1040 & $\begin{array}{l}\text { [carta de arras de García de Nájera a Estefanía de Foix]: “ "...senior Furtuni Enne- } \\
\text { conis cum Auka", CDM Rioja, ed. Rodríguez de Lama, doc. } 3 .\end{array}$ \\
\hline & 1049 & $\begin{array}{l}\text { [donación de San Miguel de Pedroso a San Millán] "sennor Garcia Azenariz, } \\
\text { dominatur Auca", San Millán, 759-1076, ed. Ubieto, doc. } 256 .\end{array}$ \\
\hline & 1049 & "sennor Garcia Azenariz, de Auca", San Millán, 759-1076, ed. Ubieto, doc. 259. \\
\hline & 1050 & $\begin{array}{l}\text { "sennor Garcia Azenariz, dominante Aucha", San Millán, 759-1076, ed. Ubieto, } \\
\text { doc. } 269 .\end{array}$ \\
\hline & 1052 & $\begin{array}{l}\text { "iuxta aqua qui dicitur Rigo de Truggillas in alfoze de Auca", Cardeña, ed. Serra- } \\
\text { no, doc. } 330 .\end{array}$ \\
\hline & 1081 & $\begin{array}{l}\text { "sennor Didaco Alvaroz dominatur Auca", San Millán, 1076-1200, ed. Mª.L. } \\
\text { Ledesma, doc. } 40 .\end{array}$ \\
\hline & 1084 & $\begin{array}{l}\text { "sennor Didaco Alvarez dominantur Auca", San Millán, 1076-1200, ed. Ma.L. } \\
\text { Ledesma, doc. } 76 .\end{array}$ \\
\hline & 1089 & "sennor Alvar Didaz de Oca", San Millán (1076-1200), ed. Mª L. Ledesma, doc. 187. \\
\hline & 1089 & $\begin{array}{l}\text { "sennor Alvaro Didaz dominatur Auca", San Millán (1076-1200), ed. Må. L. } \\
\text { Ledesma, doc. } 187 .\end{array}$ \\
\hline & 1090 & $\begin{array}{l}\text { "seniore Alvaro Didaz dominante Petroso et Aucha", San Millán, 1076-1200, ed. } \\
\text { Mª.L. Ledesma, doc. } 204\end{array}$ \\
\hline
\end{tabular}


TERRITORIALIDAD REGIA Y SISTEMAS CONCEJILES...

\begin{tabular}{|c|c|c|}
\hline Centro territorial & Año & Referencia documental a los territorios y delegados regios (siglos X-XI) \\
\hline Ojacastro? & & $\begin{array}{l}\text { "in valle qui dicitur Oggacastro", San Millán, 1076-1200, ed. Ma.L. Ledesma, } \\
\text { doc. } 153 .\end{array}$ \\
\hline \multirow[t]{6}{*}{ Pedroso } & 971 & $\begin{array}{l}\text { "trado me ad atrium Sancti Michaelis archangeli, qui est situm in Suburbio de } \\
\text { Pedroso, iuxta flumine Tirone", San Millán, 759-1076, ed. Ubieto, doc. } 89 .\end{array}$ \\
\hline & 1081 & "Alvar Diaz in Petroso", San Millán, 1076-1200, ed. Mª.L. Ledesma, doc. 44. \\
\hline & 1090 & $\begin{array}{l}\text { "seniore Alvaro Didaz dominante Petroso et Aucha", San Millán, 1076-1200, ed. } \\
\text { Ma.L. Ledesma, doc. } 204 .\end{array}$ \\
\hline & 1094 & $\begin{array}{l}\text { "seniore Alvaro Didaz regente Auca et Petroso", San Millán, 1076-1200, ed. } \\
\text { Ma.L. Ledesma, doc. } 226 .\end{array}$ \\
\hline & 1095 & $\begin{array}{l}\text { "Garsea Blascoz, merino in Petroso", San Millán, 1076-1200, ed. M.L. Ledesma, } \\
\text { doc. } 255 .\end{array}$ \\
\hline & 1099 & "Alvaro Didaz in Petroso", San Millán, 1076-1200, ed. Ma..L. Ledesma, doc. 278. \\
\hline \multirow[t]{17}{*}{ Tobía } & 1020 & $\begin{array}{l}\text { [donación a San Millán de San Cristóbal de Tobía]: "Sancti Emiliani, situm iuxta } \\
\text { castro Tobie", San Millán, 759-1076, ed. Ubieto, doc. } 171 .\end{array}$ \\
\hline & 1036 & $\begin{array}{l}\text { "sennor Garsea Fortuniones in Tovia", San Millán, 759-1076, ed. Ubieto, doc. } \\
\text { 207; con fecha de 1035, Santa Ma. Nájera, ed. M. Cantera, doc. } 5 .\end{array}$ \\
\hline & 1040 & $\begin{array}{l}\text { [carta de arras de García de Nájera a Estefanía de Foix]: “....senior Sancho Fortu- } \\
\text { nionis cum Tubia et tota sua pertinentia“, CDM Rioja, ed. Rodríguez de Lama, } \\
\text { doc. } 3 .\end{array}$ \\
\hline & 1056 & "senior Acenare Garceiz in Tubia", CDM Rioja, ed. Rodríguez de Lama, doc. 17. \\
\hline & 1058 & $\begin{array}{l}\text { "Garcia Fortunionis dominatur Toveia", San Millán, 759-1076, ed. Ubieto, doc. } \\
298 .\end{array}$ \\
\hline & 1062 & "sennor Azenari Garceiz in Tuvia", San Millán, 759-1076, ed. Ubieto, doc. 321. \\
\hline & 1065 & "Azenari Garceiz dominator Tobie", San Millán, 759-1076, ed. Ubieto, doc. 344. \\
\hline & 1066 & "senior Azenar Garceiz in Tubia", Santa Mª Nájera, ed. M. Cantera, doc. 17. \\
\hline & 1070 & "senior Enneco Azenarez in Tubia", San Millán, 759-1076, ed. Ubieto, doc. 383. \\
\hline & 1071 & $\begin{array}{l}\text { "sennor Fortun Sanchez dominator Tuvie", San Millán, 759-1076, ed. Ubieto, } \\
\text { doc. } 393 .\end{array}$ \\
\hline & 1073 & "Sancio Gartiaç in Tobia et in Anguidanos", Valvanera, ed. García Turza, doc. 66. \\
\hline & 1073 & "domno Antonino in Matute et in Villanoba", Valvanera, ed. García Turza, doc. 67. \\
\hline & 1073 & "senior Antonino Munniz in Tobia", CDM Rioja, ed. Rodríguez de Lama, doc. 27. \\
\hline & 1078 & $\begin{array}{l}\text { "et in Tubia dux Antonin Nunneç", "sub eius imperio [del rey Alfonso VI] dux } \\
\text { Antonino Nunneç", Valvanera, ed. García Turza, docs. 89, } 90 .\end{array}$ \\
\hline & $1077-83$ & $\begin{array}{l}\text { Antonino o Antolín Núñez, senior o dominante en Tobía, Valvanera, ed. García } \\
\text { Turza, docs. 76-81, 84-101, 104-122, 124-134, 135-164, 170-179. }\end{array}$ \\
\hline & 1085 & $\begin{array}{l}\text { "sennor Antolino Nunniz in Tuvia", San Millán, 1076-1200, ed. M.L. Ledesma, } \\
\text { doc. } 98 .\end{array}$ \\
\hline & 1097 & $\begin{array}{l}\text { "senior Lope Lopez, dominantur Tuvia...Et Sancho Garceiz, merino in rivo de } \\
\text { Tuvia", San Millán, 1076-1200, ed. Ma.L. Ledesma, doc. } 266 .\end{array}$ \\
\hline $\begin{array}{l}\text { Villanueva de } \\
\text { Anguiano }\end{array}$ & 1073 & $\begin{array}{l}\text { "domno Antonino in Matute et in Villanoba", Valvanera, ed. García Turza, } \\
\text { doc. } 67 .\end{array}$ \\
\hline
\end{tabular}




\begin{tabular}{|l|c|l|}
\hline Centro territorial & Año & \multicolumn{1}{|c|}{ Referencia documental a los territorios y delegados regios (siglos X-XI) } \\
\hline 1078 & $\begin{array}{l}\text { "in Tubia senior Antonino Nunneç; et in Billanoba sub eius iussione, Garçie } \\
\text { Godestioç; et iudice Domingo Scemeno et Tellu Laine saione", Valvanera, ed. } \\
\text { García Turza, doc. 85. }\end{array}$ \\
\cline { 2 - 4 } & 1081 & $\begin{array}{l}\text { "Adefonsus rex in Legione et in Nagera; et sub eius, senior Antolin Nunez in } \\
\text { Tubia; discurrente iudicio alcaldi in Matute Genneco Sabastianez; et in Villanova } \\
\text { Sancio Scemeno, adenantato", Valvanera, ed. García Turza, docs. 151, 158, 159. }\end{array}$ \\
\cline { 2 - 4 } Valle de San Vicente 1081 & $\begin{array}{l}\text { "in Tobia Antolin Nunnez; et sub illo, in Villanoba Gartia Godestioz; et iudice } \\
\text { Gartia Santioz; et saione Scemeno Enneco", Valvanera, ed. García Turza, docs. } \\
161-164 .\end{array}$ \\
\hline 1081 & $\begin{array}{l}\text { "pectet calumpniam ad partem potestatis de valle Sancti Vincentii (..) lohanne } \\
\text { Gutierrez merino in valle Sancti Vicentii", San Millán, 1076-1200, ed. Ma.L. } \\
\text { Ledesma, doc. 44. }\end{array}$ \\
\hline 1095 & $\begin{array}{l}\text { "Tello Vita, merino in valle Sancti Vicenti", San Millán, 1076-1200, ed. Ma.L. } \\
\text { Ledesma, doc. 255. }\end{array}$ \\
\hline
\end{tabular}

Pedroso se menciona como suburbium, sinónimo de territorium o alfoz, en $971^{24}$. En el siglo XI Pedroso constituía una tenencia cuyo dominante lo era también de la de Oca ${ }^{25}$.

En otros casos, la existencia de un castrum altomedieval, tuviera o no orígenes más antiguos, favoreció que acabase escogiéndose el lugar para convertirlo en alfoz y tenencia. Tobía se atestigua como castrum en época de Sancho el Mayor, según un documento de San Millán de $1020^{26}$. En el siglo XI, al frente de la localidad, varios tenentes permiten conocer la continuidad del centro territorial. No se descarta que el castillo de Matute, próximo al anterior, tuviese también un papel en la administración regia durante ese siglo. En realidad, estas dos localidades, junto con las de Anguiano y Villanueva -hoy despoblado junto a aquél-, muy próximas entre sí, eran mencionadas como centros territoriales a finales del XI. Un documento de 1078 daba a entender que la autoridad de Villanueva podía tener un papel subordinado respecto del senior de Tobía ${ }^{27}$. Y otros documento de 1081 parecen expresar una jerarquía en la que el tenente de Tobía podía contar como delegados con el de Villanueva, más un juez y un sayón ${ }^{28}$. Ese mismo año el delegado de Villanueva aparece como adenantato ${ }^{29}$.

24. San Millán, 759-1076, ed. Ubieto, doc. 89.

25. Así ocurre en menciones de 1090 y 1094, San Millán (1076-1200), ed. Ma . L. Ledesma, docs. 204 y 226.

26. San Millán, 759-1076, ed. Ubieto, doc. 171.

27. Valvanera, ed. García Turza, doc. 85.

28. Valvanera, ed. García Turza, docs. 160 a 164.

29. Valvanera, ed. García Turza, docs. 151, 158, 159. El término "adenantato" es aplicado a otros agentes de Villanueva por aquellos años, indicando quizá una condición de 'delegados de los delegados', por así decir: Iñigo Milianez, Ibid., docs. 62, 63, 132, 148, 149, de 1072, 1079-1081; o Scimeno Munio, Ibid., docs. 153-157, de 1081. 
TERRITORIALIDAD REGIA Y SISTEMAS CONCEJILES...
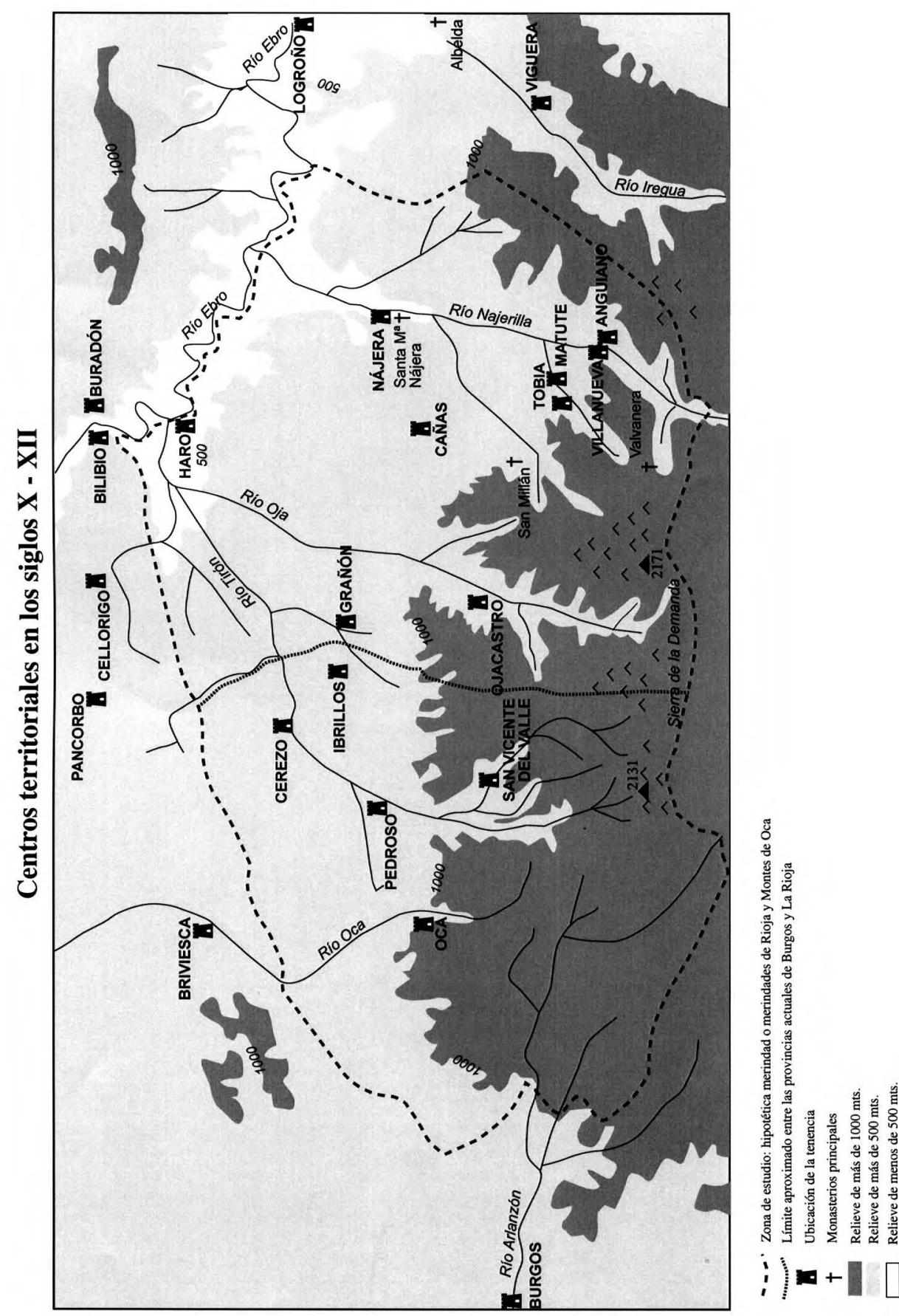
Grañón es citado en algunos documentos del X. Quizá en el origen hay también un castrum. En diploma del 999, seguramente falso, se menciona una exención fiscal dada por el conde Sancho García al monasterio de Cervatos y, al fijar los límites, se dice que no paguen portazgo desde el Duero al mar y desde Carrión a Grañón, lo que revela que se consideraba extremo oriental del Condado, pues esos eran los límites de Castilla en esa época. Grañón sería el límite con al reino de Pamplona ${ }^{30}$. Todavía en 1069 se hablaba de castro Grannione, según un diploma emilianense dado por Sancho el de Peñalén ${ }^{31}$. En los diplomas del siglo XI es destacado como importante centro territorial. Como muchos otros, el de Grañón había sido también citado en la célebre carta de arras otorgada por García Sánchez III a Estefanía de Foix en 1040², en ese caso con el nombre de mandatio, que es sinónimo de tenencia. Grañón estaba gobernado en 1090 por el conde García, que también tenía Nájera ${ }^{33}$.

Como puede apreciarse, y basten los casos reseñados, los orígenes de alfoces y tenencias no eran los mismos y la realidad no era estática. De otras localidades no hay información tan segura como en los casos $\operatorname{citados}^{34}$. Es posible también que algunos valles, incluso aunque estuvieran históricamente organizados a modo de castra altomedievales, pudieran haberse visto reconvertidos en tenencias en algún momento. Suponemos que tanto el llamado poblamiento "castral», con un castrum elevado y jerarquizador del espacio, como el modelo «comunidad de valle», entendida ésta como un espacio comunitario integral de origen prefeudal, parecen posibles morfologías históricas que dieron lugar a los centros territoriales de las áreas montañosas. No se conoce, sin embargo, con detalle si alguno de estos procesos evolutivos sería aplicable a Ojacastro o Val de San Vicente, en la zona de estudio. El valle de Ojacastro se menciona en documentos del siglo XI, pero no hay evidencias claras de su dimensión administrativa. Es posible que a partir del valle se hubiesen levantado enclaves forti-

30. La exención supuestamente la tendrían los monjes "de Dorio flumine usque ad ripam maris et de Carrione usque ad Grannonem", Col. Diplom. Condes de Castilla, ed. Zabalza, doc. 61.

31. San Millán, 759-1076, ed. Ubieto, doc. 376.

32. CDM Rioja, ed. Rodríguez de Lama, doc. 3.

33. San Millán (1076-1200), ed. Ma. L. Ledesma, doc. 202.

34. Hay que decir que algunas informaciones hacen dudar de la condición de tenencias de algunos enclaves (hecho, por otra parte, lógico, dado que fue algo relativamente cambiante). Pero hay otro tipo de dudas de corte más prosaico. Por ejemplo, la tenencia de Azofra (próxima a Nájera) podríamos pensar que existe si tenemos en cuenta la mención al "senior Azenarii Fortunionis de Azafra", CDM Rioja, ed. Rodríguez de Lama, doc. 4, de 1044. En otro documento de 1046 se menciona al "senior Eximino Garzeiz de Azafra", Ibid., doc. 8. Pero es que ese mismo personaje, Eximino Garcéiz, es citado por aquellos años como senior de Azagra (Azekra, Azagra), Ibid., docs. 11 y 17. En 1081 existe una mención al dominante en Nájera y Azofra, Ibid., doc. 37. 
ficados o castra, en lo que sería una arcaica organización política para defender o para controlar el valle, pero no es seguro que en la época que nos interesa funcionasen ya como centros territoriales. El castrum de Oja, que es el fundamento del topónimo, podría haber tenido un ámbito desde el que se habría controlado en época protofeudal el espacio ribereño y montañoso de la cuenca alta del río, pero habría perdido ya en el siglo XI su sentido originario. Sobre todo, esta desnaturalización se habría producido si se piensa que en algún momento poco anterior había persistido como realidad gentilicia. Pero el valle como tal, es decir, simplemente considerado como una amplia zona forestal y de pastos, era percibido en el siglo XI como un espacio de actuación definido, como bien sabía San Millán, y en menor medida Valvanera, que lo veían como área de expansión pecuaria ${ }^{35}$. En el caso de Valle de San Vicente, la otra gran entidad de la zona de estudio nacida presumiblemente en una comunidad de valle, se menciona un merino en 1081 y después ${ }^{36}$. Parece que este valle siguió siendo una unidad y todavía a finales del XII constituía una entidad encuadrada en las estructuras de la monarquía, quiero pensar que funcionando como lo que considero realengo directo ${ }^{37}$.

Algunos centros, aparte de los citados, tuvieron su apogeo tenencial en el siglo XI. Y otros sólo destacaron ya en época de Alfonso VI o después, habiendo tenido un pasado totalmente gris en las etapas de Pamplona y Nájera. Este

35. Valvanera, ed. García Turza, doc. 190, de 1092. El valle de Canales, más al sur pero fuera de la zona de estudio, tendría una situación semejante. Es significativo que en ese documento, en que Alfonso VI otorgaba la comunidad de pastos del monasterio de Valvanera con varias localidades vecinas se distinguía entre la comunidad de pastos con aldeas, esto es, "peccora comunem habeant cum villa Matute et Tubia et Villanova et Anguidanos et Matrice", por una parte, y lo que eran valles, por otra, es decir, "valle de Ogacastro et villas dictas quinque et valle de Canales". El valle entendido como unidad. Esto no quiere decir que no hubiese villae o lugares poblados en él, sino que se entendían como piezas de un conjunto: en una comunidad de pastos supuestamente anterior -la fecha expresa del documento es 1053-, en este caso hecha a favor de San Millán, el convenio lo acordaba el monasterio "cum omnibus illis villis Oiacastrensibus". Pero no eran los lugares singularmente los que rubricaban el pacto sino "nos omnes concilii Oiacastrensi", San Millán, 1076-1200, ed. Ma . L. Ledesma, doc. 287 bis. En otro documento de 1087 con la donación de Alfonso VI a San Millán del cenobio de San Sebastián se decía que éste se hallaba "in valle qui dicitur Oggacastro", San Millán, 1076-1200, ed. Mª. L. Ledesma, doc. 153. Quizá al frente del valle Diego Álvarez era quien ejercía de tenente.

36. San Millán (1076-1200), ed. Ma. L. Ledesma, doc. 44; Ibid., doc. 255, de 1095. Recientemente, fruto de un trabajo de Grado o de Suficiencia Investigadora de la Universidad de Burgos, se ha publicado el estudio de PETERSON, D., La Sierra de la Demanda en la Edad Media. El Valle de San Vicente (siglos VIII-XII), Logroño, 2005, que esperemos tenga continuidad en otras investigaciones del autor sobre la zona.

37. Un documento de Alfonso VIII de 1191 hablaba de "in terram fidelitatem Vallis de Sancto Vincentio", Documentación del monasterio de las Huelgas de Burgos (1116-1230), ed. Lizoain Garrido, J.M., Burgos, 1985, doc. 29. 
parecería ser el caso de Haro. Esta localidad, tras estar asociada a Bilibio durante mucho tiempo, tardó en percibirse como tenencia única ${ }^{38}$.

Lo cierto es que todos estos alfoces regios, o territoria, Ilamados en alguna ocasión también mandaciones, y derivados como decíamos de situaciones diversas -civitates, castra tardoantiguos o protofeudales, valles, castillos fronterizos o levantados con la expansión repobladora por pamploneses o castellanos-, al irse afirmando la monarquía feudal, fueron fraguando como sus unidades territoriales a escala supraaldeana. Fueron una instancia intermedia entre la corte gobernante y las comunidades campesinas. Incluso en la imaginación del escriba de San Millán, que hacia 1140 o después falsificó un célebre diploma legitimando al monasterio para percibir un tributo de los castellanos, los alfoces se citaban profusamente entre los distintos territorios de Castilla. En esos votos de San Millán el espacio del Condado de Castilla de la época de Fernán González, supuestamente de 934, aparece organizado de forma preferente en alfoces ${ }^{39}$. Era una invención, como hace ya mucho tiempo hizo ver muy oportunamente García de Cortázar, pero esta geografía imaginaria de la Castilla primigenia demuestra que a mediados del XII en el scriptorium emilianense, centro de cultura, se tenía asumida la antigüedad y arraigo de esa forma de administración del territorio.

Poco sabemos de la condición de los tenentes y de otra parte de la oficialidad delegada regia ${ }^{40}$. Los tenentes eran denominados generalmente seniores. Otros nombres comunes que tenía el cargo eran dominus, dominante, regente, que aludía a la función de delegación del poder regio, o se decía de alguien "que tenía" tal o cual localidad, o que regía "in" dicha localidad. La palabra "potestas", "potestate", es más imprecisa pero también se utilizó. Siempre era un miembro de la aristocracia, ya fuera en nuestro caso pamplonesa, najerense o castellana. El hecho de que al frente de las tenencias o castillos regios hubiera comites no quiere decir que el centro como tal fuera cabeza de un «condado", sino que el rango o estatus del tenente era ése. Algunos comites aparecen al frente de tenencias de forma sistemática. Durante la época pamplonesa solían serlo los tenentes de Nájera, por ejemplo. A finales del siglo XI un comite estaba al frente de Cerezo y de toda Bureba ${ }^{41}$. Son situaciones en la cima de la tenencia caracterizadas por cierta elasticidad. En cambio, el merino del alfoz o de la tenencia, maiorinus de rege, aunque también era una pieza importante en

38. Con Diego López al frente se cita en un documento de 1117, CDM Rioja, ed. Rodríguez de Lama, doc. 54.

39. Editado en San Millán, 759-1076, ed. Ubieto, doc. 22. Para la zona de estudio se citan varios: Oca, Cerezo, Grañón, Bilibio, además de los cercanos Pancorbo, Briviesca, Cellorigo, Término, Buradón, etc.

40. En esto están de acuerdo quienes se han acercado al tema. Entre ellos, GARCíA DE CORTÁZAR, J. A., "La organización social del espacio en la Rioja cristiana en los siglos X y XI", cit., págs. 136-139; PEÑA BOCOS, E., "Alfoces y tenencias: La Rioja", cit.

41. San Millán, 1076-1200, ed. Mª. L. Ledesma, doc. 278. 
la administración de la misma, tenía menor peso político. Era una autoridad diferenciada de la del senior o tenente ${ }^{42}$. Las funciones de los merinos de la tenencia, básicamente tareas fiscales, serían similares en su jurisdicción a las que ejercían los merinos de los dominios señoriales, sobre todo eclesiásticos. Lógicamente, los merinos de las tenencias, que serían los merinos de los dominios del rey, recaudaban los tributos en las villas ${ }^{43}$ y solares realengos que hubiese en el ámbito de la tenencia. Sayones eran oficiales aún de menor rango en las tenencias, para tareas fiscales o judiciales, pero auxiliares. En algunas de las tenencias en determinados momentos actuaban iudices regios, lo que no quiere decir que hubiese una dotación de estos oficiales desplegada en todas ellas. Desde el punto de vista material, el castillo regio expresaba el poder de la tenencia, al margen de que hubiera otras fortificaciones en la misma zona ${ }^{44}$, en este caso sin esa función administrativa. Por otra parte, como ya decíamos, la tenencia no es algo diferenciado y necesariamente posterior al alfoz, como si un régimen tenencial desde mediados del XI hubiese sustituido a un régimen de alfoces de forma universal. De hecho, la palabra alfoz, y su contenido básico, siguieron existiendo, y a veces predominando, como nombre del territorio, mientras que la palabra tenencia realmente no se consolida hasta el siglo XII, y no en todas partes.

¿Que significaban los centros territoriales desde el punto de vista de la territorialidad regia? Nos interesa responder a esta cuestión para, más adelante, hacer la comparación con la aparición de las villas nuevas. Pues bien, lo que he observado en otras partes, tanto en la Castilla septentrional como en el reino de León, en los siglos XI-XII, me parece percibirlo también en estas áreas riojanas. A mi juicio, las tenencias regias, o alfoces regios, ofrecen un haz de situa-

42. A veces, como ocurre con los tenentes, se menciona a los merinos alfoceros en los documentos entre los testigos, prueba de su papel. Pero no hay identificación con el tenente. Por ejemplo, en un documento de 1090 de San Millán se menciona al final al conde García, como tenente de Grañón, y luego a "Garsia Blascoz, merino in Granione".

43. Una pequeña aclaración. Reservo la palabra «villa», en letra normal, para las realidades capitalinas o concejiles, con sus campos afines: "villas nuevas", "pueblas nuevas", "concejo de la villa", etc. Y uso en cambio la cursiva - «villas», «villae»- cuando me refiero a los simples núcleos rurales, ya aparezcan en latín o en castellano, al margen de que estuvieran o no encuadradas en los sistemas concejiles. Se trata de distinguir precisamente las cabeceras de las villas de estos últimos de lo que eran simples lugares, superando la polisemia de los textos. En consecuencia, hablo de «aldeas» o "lugares», si entiendo que lo eran, pese que en las fuentes de la Castilla septentrional estos núcleos rurales fueran denominadas en muchas ocasiones "villas", tanto en latín como en castellano, es decir, la misma palabra que se empleaba para las capitales concejiles, ya que en el norte de Castilla la voz romance "aldea" no desplazó universalmente a la antigua palabra latina "villa" para referirse a los núcleos rurales.

44. Un inventario, y estudio técnico, de castillos y fortificaciones medievales de la actual provincia de La Rioja, con muchas fotografías, se halla en el libro de MOYA VALGAÑÓN, J. G., RUIZ-NAVARRO, J., ARRÚE, B., Castillos y fortalezas de La Rioja, Logroño, 1992. 
ciones cuando menos paradójicas: aparentemente favorecían al rey, ya que no fueron enajenadas en clave "feudal" típica, sino que sustentaron la presencia fiscal, militar y pública del poder regio; pero paralelamente favorecían también a la nobleza, pues se puede argumentar que eran resortes desde los cuales los miembros de la aristocracia de primera fila ejercían influencia sobre los territorios, controlaban vasallos y rentas; otro aspecto paradójico es que las tenencias aparentan ser un tipo de poder concentrado y aparentemente aglutinante, al desplegarse sobre un territorio definido, gobernado desde un castillo del rey que servía de capital a un espacio conocido. Creo que en todo esto hay cierto espejismo. Aunque tengo menos evidencias para esta zona que para otras $^{45}$, pienso que pueden proponerse algunas hipótesis sobre los efectos del régimen de tenencias en la viabilidad estructural de la territorialidad regia. Sintéticamente, creo que hay tres conceptos que resumen estas hipótesis: acumulación nobiliaria, pérdida de dominio regio y desagregación espacial.

Los detentadores de las tenencias, miembros siempre de la aristocracia, hallaron en ellas una vía para reforzar su poder. Las tenencias aportaron ingresos y, aunque no les proporcionaran el señorío de lugares concretos, algunos miembros de la aristocracia sí dieron pasos para ello y, además, se enriquecieron. Lo que percibimos es que la nobleza, sirviendo al rey, no se desgastaba, sino que se reforzaba. Casi todos los tenentes aparecen en la documentación también como integrantes de la corte regia, tanto pamplonesa como castellana, en este caso desde 1076. Sus patrimonios son invisibles para el historiador, ya que casi nunca se citan como dueños de villae íntegras. En parte ello es debido a la documentación, pero podemos intuir que ya desde esta época tenían muchas divisas, con las que podrían haber conseguido fortunas, si bien con un dominio parcial y fragmentado, propio de esa modalidad. Si en los siglos XIII y XIV afloran en la documentación estas divisas, solares y algunos lugares en manos de hidalgos ${ }^{46}$, es porque en los siglos anteriores disponían de ellos. La documentación no permite conocer el patrimonio de los magnates, pero es casi seguro que se nutría, cuando menos, de este tipo de derechos y heredades ${ }^{47}$ que fueron características de la infanzonía, pero en el caso de los magnates en una gran escala e incluyendo además lugares íntegros. El control de una tenencia allanaba, sin duda, el campo de los aristócratas para incrementar este tipo de adquisiciones dominiales.

45. Áreas de la actual provincia de Burgos (vid. títulos de nota 4); o del reino de León, MONSALVO ANTON, J. Ma ., "De los alfoces regios al realengo concejil en el reino de León (1157-1230). La territorialidad de las ciudades y las villas reales entre la Cordillera Cantábrica y el Duero", en VV.AA., El Reino de León en la época de las Cortes de Benavente, Benavente, 2002, pp. 29-100, esp. 39-50.

46. Vid. algunos ejemplos de las aldeas próximas a Santo Domingo de la Calzada infra, nota 160.

47. GARCÍA DE CORTÁZAR, J. A., "La organización social del espacio en la Rioja cristiana en los siglos X y XI", cit., p. 122. 
Pero además, en esa misma idea de acumulación de poder por parte de la nobleza, se detecta una posible tendencia a la patrimonialización tácita de las mismas. Se repiten los personajes. Y sabemos además que, en ocasiones, un mismo noble agrupaba varias tenencias. Aznar Fortúnez tenía en 1040 asociadas las de Bilibio y $\mathrm{Haro}^{48}$. Sancho García tenía en 1073 las tenencias de Tobía y Anguiano ${ }^{49}$. Y Tobía y Matute estaban en 1080 en manos de Antonino Núñez ${ }^{50}$. Alvaro Díaz tenía en la última década del siglo XI las de Oca y Pedroso ${ }^{51}$. En 1090 también el conde Gomesano regía las de Cerezo, Pancorbo y Piedralada ${ }^{52}$ y el conde García Ordóñez sumaba las de Nájera y Grañón ${ }^{53}$. Sabemos también que era posible que el tenente delegara en otro el cargo o la función: en 1073 era tenente de Ibrillos el senior Diego Álvarez pero "sub ille" estaba el senior Diego Gudestioz ${ }^{54}$. En esa misma tenencia Diego Álvarez contó en aquellos años, como en 1089, con otro delegado, Blasco Díaz ${ }^{55}$. Otro caso de tenencias múltiples lo protagoniza hacia 1079-1081 Pedro Juanes en Nájera, quizá Azofra y otros enclaves ${ }^{56}$, aunque sometido en Nájera a una autoridad condal superior.

Más allá del siglo $\mathrm{XI}^{57}$ los tenentes siguieron acumulando influencia y reproduciendo las tendencias observadas, incluso coexistiendo ya con las nuevas realidades concejiles. Es seguro incluso que algunos de los grandes linajes nobiliarios castellanos forjaron en el control de las tenencias el despegue de briIlantes estirpes. No pretendo hacer una historia de la nobleza castellana o riojana, naturalmente, pero conviene no olvidar este efecto robustecedor de los nobles que proporcionan las tenencias. Quizá el caso más significativo de la zona se refiere a la casa de Haro. Íñigo López aparece al frente de la tenencia de Nájera en pleno reinado de Sancho IV de Pamplona ${ }^{58}$. Fue pieza clave en el

48. CDM Rioja, ed. Rodríguez de Lama, doc. 3.

49. Valvanera, ed. García Turza, doc. 66.

50. Valvanera, ed. García Turza, doc. 133.

51. San Millán, 1076-1200, ed. Mª. L. Ledesma, docs. 204, 226.

52. "Comite Gomessano in Cereso et in Ponticurbo et in Petralata", San Millán, 1076-1200, ed. Ma. L. Ledesma, doc. 201.

53. Documentos de 1089 y 1090, San Millán, 1076-1200, ed. Ma. L. Ledesma, docs. 191, 202 y 203. En esos años, en referencia a otras tenencias fuera de la zona, Gundisalvo Núñez era tenente de Lara y Los Ausines, San Millán, 1076-1200, ed. Ma . L. Ledesma, doc. 226. Y en 1040 el conde Nuño Gundisalvo tenía las tenencias de Cellorigo, Término y Lantarón, CDM Rioja, ed. Rodríguez de Lama, doc. 3.

54. Valvanera, ed. García Turza, doc. 68.

55. Diego Gudestioz se cita como delegado de Diego Álvarez en documentos de 1075 y 1078, Valvanera, ed. García Turza, docs. 72 y 102. En 1089 Diego Álvarez se cita como dominans de Ibrillos y su delegado era Blasco Díez, Ibid., doc. 188.

56. Valvanera, ed. García Turza, doc. 165; CDM Rioja, ed. Rodríguez de Lama, doc. 37, entre otros.

57. En el Anexo adjunto no hemos alargado al siglo siguiente el cuadro de tenentes, pues no parece ya necesario para corroborar las ideas que exponemos en torno a estas figuras.

58. Valvanera, ed. García Turza, docs. 31, 45- 49, de 1064, 1068-1069. 
proceso por el que Alfonso VI incorporó en 1076 las tierras de La Rioja. Poco antes de la muerte del navarro en Peñalén mantenía esta tenencia ${ }^{59}$. Es sabido que Alfonso VI colocó al frente de Nájera al conde García Ordóñez, leal al castellano pero casado también con Urraca, hermana del rey pamplonés desaparecido. Pero cuando esto ocurrió Íñigo López, el anterior hombre fuerte del castillo regio de Nájera, no sólo no se vio perjudicado. El mismo año de 1076 es citado en la documentación de San Millán donando el lugar de Camprovín al monasterio. Esta donación ${ }^{60}$ muestra un par de aspectos interesantes: lo primero, que Íñigo López, seguramente en la época de su tenencia, había adquirido bienes en la zona, sin ir más lejos, esa villa, y siempre hemos de suponer, como hemos indicado, mayor patrimonio del que aflora en las colecciones documentales, de lugares enteros quizá, como es el caso, pero también, por supuesto, de divisas y portiones varias; lo segundo, que el tal Íñigo López aparece en ese documento como "tocius Vizcahie comes", conde de Vizcaya. No conocemos todas las influencias, sin duda, pero es evidente que las tenencias riojanas habrían tenido incidencia en el encumbramiento de los miembros de la casa de los señores de Vizcaya, de la que el personaje sería el primer "señor". No seguiremos la estela de este linaje, que no tiene aquí lugar. Digamos simplemente que no descuidaron durante mucho tiempo su preocupación por las tierras riojanas. Diego López I de Haro, dos generaciones después de Íñigo López, se enfrentó, desde la tenencia de Haro, donde construyó un castillo, a Alfonso el Batallador, según consta en $1116^{61}$. Más tarde, su hijo el conde Lope Díaz I de Haro recuperó influencia en la región riojana con Alfonso VII, siendo tenente de Nájera hasta su muerte en 1170. Y más tarde, ya su hijo Diego López II de Haro alcanzó posiciones de primer orden en época de Alfonso VIII, de quien fue alférez, pero además mantuvo posiciones influyentes en la zona de estudio, desde Belorado y Cerezo hasta incluso Logroño, además de Miranda, Cellorigo, Haro y Nájera. Algunos de los problemas de los miembros de esta casa, entre ellos este todopoderoso Diego López II de Haro, hacia 1200, se debieron precisamente al propio arraigo en la zona ${ }^{62}$.

Lo cierto es que las tenencias, asociadas a aldeas, divisas, rentas y maniobras políticas, máxime en una zona fronteriza y de delicado equilibrio entre castellanos y navarros, daban a los nobles excesivo poder, viendo la cuestión desde la perspectiva de los reyes. Era uno de los graves efectos que el régimen de tenencias tenía para la monarquía. Es cierto que, como indicaremos, cuan-

59. Valvanera, ed. García Turza, doc. 71, entre otros documentos de la época.

60. San Millán, 1076-1200, ed. Ma . L. Ledesma, doc. 2.

61. "In ipso castello novo ante Farum, quando Didaco Lopiz erat in guerra cum rege, iam dicto Adefonso", Valvanera, ed. García Turza, doc. 208, de 1116.

62. Alfonso VIII aprovechó la enemistad transitoria con él, que entre otras cosas le llevó a pasarse a Navarra contra Castilla, para arrebatar a Diego López de Haro la aldea de Bardauri y dársela a la flamante villa de Miranda de Ebro, Alfonso VIII, ed. J. González, doc. 769. 
do la tenencia se solapaba a una villa nueva, el poder emanado de ella cambiaba cualitativamente, en detrimento precisamente de su vieja naturaleza político-administrativa, pero ello no era óbice para que, incluso en esos casos, todavía siguiese siendo importante como fuente de rentas, cuando menos.

Pero había un segundo efecto perverso de las tenencias para el poder real y creo que era su incapacidad para proteger eficazmente el dominio del rey de enajenaciones. Los monarcas tradicionalmente venían ganando lealtades y apoyos aristocráticos, precisamente por la naturaleza de su poder feudovasallático, canjeando su dominio, pero a costa de la mengua de éste. Sobre todo en favor de los grandes monasterios. Lo que constatamos en la zona, como en otras, es un deterioro rampante del dominio regio, una sangría de donaciones de aldeas totalmente irreversible, ya que la Iglesia incorporaba casi compulsivamente donaciones, que lo eran sin retorno posible salvo casos absolutamente excepcionales. No es necesario insistir en este argumento porque, justamente a contrario, es el mismo que el de la formación de los dominios monásticos, tema clásico donde los haya del medievalismo castellano y riojano. El auge de estos grandes patrimonios se apoyaba en una dotación de dominio, pero también la concesión de la inmunidad o jurisdicción, que pasaba del realengo al monasterio. En la zona fue muy pujante la expansión de algunos grandes monasterios, perfectamente estudiados: San Millán de la Cogolla -que fue el más importante- Albelda, Valvanera y Santa María de Nájera fueron las grandes $\operatorname{casas}^{63}$ que se hicieron con numerosos lugares, pequeños monasterios locales y derechos diversos ${ }^{64}$. Pero esto suponía una degradación constante y un ataque a la línea de flotación de lo que podía ser la continuidad física del realengo en determinadas comarcas. No hay más que ver los mapas de dominios para darse cuen-

63. Hay estudios y monografías donde comprobar la expansión de los dominios citados: GARCIA DE CORTAZAR, J.A., El dominio del monasterio de San Millán de la Cogolla (ss. X-XIII). Introducción a la Historia rural de Castilla altomedieval, Salamanca, Universidad, 1969; GARCIA TURZA, F. J., El monasterio de Valvanera en la Edad Media (ss. XI-XV), Madrid, 1990; ID., "Los espacios de poder en la Rioja medieval", en J. I. de la Iglesia (coord.), Los espacios de poder en la España medieval. XII Semana de Estudios Medievales (Actas Congreso de Nájera, 2001), Logroño, 2002, pp. 483-509; CANTERA MONTENEGRO, M., Santa María la Real de Nájera, siglos X-XIV, Madrid, 1987.

64. García de Cortázar ha observado esto en el actual espacio riojano para el siglo XI, antes de 1076. Al margen de que hubiera reyes más proclives a las donaciones (por ejemplo García el de Nájera donó 10 villae; otros, un número menor), la tendencia a la enajenación del realengo en favor de los grupos altos eclesiásticos y laicos fue una constante. El autor resume algo de la riqueza patrimonial de los monasterios riojanos antes de 1076: San Millán había recibido hasta entonces 29 villae, además de 32 monasterios e iglesias; Santa María de Nájera, fundada en 1052,19 villae, más 37 iglesias y monasterios; Albelda, 4 lugares y 6 iglesias y monasterios; Valvanera, fundada hacia 1035, había incorporado 3 iglesias y monasterios, sin tener entonces lugares íntegros, aunque sí contaba con modestas posesiones, GARCÍA DE CORTÁZAR, J. A., "La organización social del espacio en la Rioja cristiana en los siglos X y XI", págs. 117, 124, entre otras. 
ta de que en algunas áreas buena parte del espacio había dejado de ser realengo y formaba parte de los dominios monásticos. Por ejemplo, lugares cercanos a la ciudad de Nájera ${ }^{65}$. Incluso castillos regios o modestas tenencias en declive o desuso podían pasar a formar parte de dichos dominios ${ }^{66}$.

Un tercer gran efecto observamos en el régimen de tenencias: la falta de cohesión espacial que conllevaba, algo que siempre olvidan los medievalistas al estudiar una determinada zona. La degradación del entorno espacial de las villas al ser enajenadas éstas contribuía a ello, pero además en el régimen de tenencias no existía ningún aglutinante potente entre los lugares que pertenecían al alfoz. La relación del tenente o merinos era con cada lugar en singular, pero nada conectaba los lugares entre sí, con la salvedad quizá de viejas solidaridades relictas en el caso de las posibles comunidades de valle. Pero, fuera de esta posibilidad, prácticamente nada. El hecho de pertenecer a un distrito regio no aseguraba unidad de fuero, judicial, de mercado, etc., que son precisamente los ingredientes que aportará el sistema concejil al que nos referiremos ahora.

El definitiva, podría decirse que el realengo organizado en alfoces o tenencias no era a esas alturas, siglos XI-XII, óptimo para la gestión de las relaciones del poder regio con sus subordinados. En ese sentido, era una estructura anticuada y sin demasiado porvenir, propia de una monarquía feudal. En este tipo de monarquía el poder regio principalmente se concretaba en el dominio, como un señorío más, eso sí, con la salvedad de la superioridad feudovasallática y de prestigio propio de los monarcas, que por otra parte fueron los recursos genuinos que permitieron impulsar los cambios estructurales de la monarquía.

Y a eso vamos. Porque, en efecto, los déficits señalados comenzaron a ser superados por los reyes en los siglos XII-XIII. Y lo hicieron de dos maneras simultáneamente. Una de ellas fue la elevación del poder regio por encima del dominio y las jurisdicciones particulares, es decir, la creación de instrumentos de

65. El mapa del dominio de San Millán permite apreciarlo en un solo vistazo, GARCIA DE CORTAZAR, J.A., El dominio del monasterio de San Millán, págs. 184-185. En concreto, San Millán se hizo con Villagonzalo-Baradán, Cárdenas, Cordovín, Ventosa, Camprovín. Y en ese área Santa María de Nájera había incorporado Arenzana de Arriba, Alesón, Cañas, Torrecilla, Somalo, Santa Coloma, Canillas y Ciruñuela. Otras localidades próximas, como Hormilleja y Hormilla formaron parte de otros dominios eclesiásticos. Vid. GARCIA TURZA, J., "Ciudades y aldeas: Nájera", en J. A. García de Cortázar (ed.), Del Cantábrico al Duero, cit., pp. 230-261, pág. 247; GARCÍA DE CORTÁZAR, J. A., "La organización social del espacio en la Rioja cristiana en los siglos X y XI", pág. 158; CANTERA MONTENEGRO, M., Santa María la Real de Nájera, siglos X-XIV, Madrid, 1987, t.I, p. 345, con el mapa de las villas que el monasterio tenía en La Rioja.

66. Villanueva pasa casi en su totalidad al dominio de Valvanera a lo largo del XI. Lo señala en un estudio sobre el lugar GARCIA TURZA, F. J., "Las aldeas de la Rioja medieval. El ejemplo de Villanueva", Il Semana de Estudios Medievales (Nájera, 1991), Logroño, 2001, pp. 233 241, p. 238. No obstante, todavía se cita el delegado regio en ese lugar en 1101: "Sancio Didaz senior in Villanoba", Valbanera, ed. García Turza, doc. 192. 
gobierno, ley y justicia regios que ya no hicieran depender al monarca sólo de la gestión del dominio realengo. Desde el punto de vista político y administrativo, esta evolución condujo a la creación de instancias territoriales por encima de los alfoces, esto es, merindades menores ${ }^{67}$, además del nacimiento de una legislación y fiscalidad centralizadas a partir del siglo XIII ${ }^{68}$. El otro gran cambio, que es el que aquí nos interesa ahora, supuso, utilizando terminología propuesta en otros trabajos nuestros, el paso del «realengo directo» al «realengo transferido».

\section{El «realengo transferido»: despliegue de los sistemas concejiles}

¿Cuando empieza a haber en la zona de estudio 'sistemas concejiles'? Hace años propusimos la expresión «sistema concejil» para poder designar también en los siglos centrales medievales los nuevos poderes asociados a los concejos de ciertas villas y ciudades. Se trata de poderes históricamente dados que tendrían la cualidad de funcionar ya como sistemas complejos y que, aunque en esa época -por deficiencia de las fuentes- no podamos estudiarlos en su interioridad de ese modo, sí eran realidades identificables y además mediante parámetros tangibles, que se pueden medir o concretar y comparar en alguna medi$\mathrm{da}^{69}$. Se trata de huir de la ambigüedad y polisemia de voces como "villas", "villas nuevas" ,"concejos", "burgos", "ciudades" "municipio urbano", "municipio rural", "concejo de villa y tierra", entre otros. Estas y otras palabras las utilizamos en su contexto y significado preciso, claro está, pero no pueden servir como común denominador para referirnos a las entidades que, en un momento determinado, empezaron a concentrar funciones que antes sólo desempeñaban los sectores altos de la sociedad.

El nuevo poder lo fue tanto por la forma como por el contenido. Pero, naturalmente, hay que saber qué tipo de requisitos mínimos buscamos. Tal como hemos expuesto en otros trabajos ${ }^{70}$, para que podamos hablar en rigor de sistema concejil hemos de detectar varios requisitos -los tres primeros, imprescindibles- en un concejo: a) autoridades propias; b) funciones político-administrati-

67. Me remito a ALVAREZ BORGE, I., Monarquia feudal y organización territorial, cit.

68. Nos interesamos por esta cuestión en "Crisis del feudalismo y centralización monárquica castellana (observaciones acerca del origen del "Estado Moderno» y su causalidad)", en C. Estepa, D. Plácido, J. Trías (eds.), Transiciones en la Antigüedad y feudalismo, Madrid, FIM, 1998, pp. 139-167.

69. El concepto de sistema concejil lo hemos empleado ya con valor estrictamente sistémico para la Baja Edad Media, cuando las fuentes lo permiten.

70. MONSALVO ANTÓN, J. Mª., "La formación del sistema concejil en la zona de Burgos", así como "Los territorios de las villas reales", cits., ID., "De los alfoces regios al realengo concejil en el reino de León", cit., todo ello en relación con el norte del Duero. En cuanto a los concejos de villa y tierra, entre otros, vid. nuestro "Frontera pionera, monarquía en expansión y formación de los concejos de villa y tierra. Relaciones de poder en el realengo concejil entre el Duero y el Tajo (c. 1072-c. 1222)", Arqueología y territorio medieval, 10. 2, 2003, pp. 45-126. 
vas y fiscalidad transferidas; c) ámbito específico de proyección territorial y espacial del concejo mismo; d) finalmente, estatuto jurídico característico de la vecindad concejil. Todo esto surgió con bastante dificultad, paulatinamente y con variantes según los sitios. Por supuesto, lo que interesa no es detectar esos requisitos, que es una simple herramienta, sino ver las vías y procesos hacia el sistema concejil, es decir, cómo fueron emergiendo, y en qué grado, los requisitos en cada sitio, empujados por diferentes fuerzas y factores históricos, en cuya diversidad hemos de comprender la personalidad diferente de cada zona ${ }^{71}$. A diferencia de los concejos de villa y tierra, al norte del Duero la formación de los sistemas concejiles fue un largo proceso, no algo súbito o fruto de una irrupción acelerada, como allí. Interesa observar cuáles fueron en la zona de estudio las estrategias del poder para fundarlos, los estímulos para provocarlos o sostenerlos y el alcance o medida de su despliegue.

Uno de los primeros atisbos de requisitos del sistema concejil no sólo de la zona sino de toda Castilla septentrional es posible que precisamente podamos encontrarlo en Nájera. Su Fuero de 1076 registra rasgos que podrían apuntar en esta dirección, algo significativo aun cuando la cronología que se atribuye a este texto ${ }^{72}$ presente ciertas dudas.

Nájera, como vimos, era ya una urbs en los siglos X y XI, con unas indudables actividades de mercado. Todo ello en un grado modesto y mal conocido, como es propio de la época, pero que permite hablar ya de una aglomeración con una vocación urbana, que la propia morfología urbana y funcional demuestran. La plaza de mercado, que podría detectarse para el siglo XI, coexistiría con el castillo regio y con el monasterio de Santa María la Real, fundado en 1052, como puntos neurálgicos de la ciudad.

Desde este punto de vista podemos considerar que Nájera participaba de uno de los factores estimulantes del sistema concejil al norte del Duero: el

71. Entre estos factores causales o estimulantes, dependiendo de la zona, hemos identificado los principales: el factor "frontera», en el sentido elástico que tiene el glacis repoblador de las Extremaduras; la presión de los burgenses; el potencial de lo que se ha llamado «sistema urbano», o sea, la combinación de ingredientes como gran volumen de población urbanizada, diversidad ocupacional, comercio permanente, etc.; y las estrategias programadas del poder regio bien para reconvertir viejos centros territoriales en villas nuevas con sistema concejil, bien para fundar ex nihilo tales villas nuevas con todos los requisitos del sistema concejil. Vid. títulos de nota anterior, que nos eximen ahora de detallar estos factores pormenorizadamente.

72. Editado en varias ocasiones, entre ellas en "Fueros de la Rioja", ed. Martínez Díez, doc. 9; Alfonso VI. Cancillería, curia e imperio. II. Colección Diplomática, ed. A. Gambra, doc. 41. El original no se conserva. Martínez Díez o Gambra dan por buena la fecha oficial, si bien este último comenta que A. $M^{a}$. Barrero sostiene que la fecha es de c.1140. Y en efecto, también es la datación que ofrece esta especialista en el libro BARRERO GARCIA, A.M ${ }^{a}$., ALONSO MARTIN, Ma.L., Textos de derecho local español enla Edad Media. Catálogo de fueros y costums municipals, CSIC, 1989, p. 324. 
potencial «urbano» o de «sistema urbano». Pero además converge en la ciudad con otro gran factor estimulante en el norte del Duero, el Camino de Santiago. Es significativo que tanto Sancho Garcés como Alfonso VI favorecieron que los núcleos del Camino recibieran un derecho especial, el influencias de francos. El sistema concejil al norte del Duero incluye este tipo de influencias entre sus bases jurídicas, si bien este derecho es condición necesaria pero no suficiente para la aparición del mismo. Efectivamente, la ruta jacobea, además de ser motivo del típico plano longitudinal del urbanismo najerense, permitió a Alfonso VI facilitar la instalación de hospitales, albergues, peregrinos y comerciantes. Existían unos fueros anteriores dados por Sancho III. Alfonso VI los renovaba en 1076. Años más tarde, a la muerte de Alfonso VI en 1109, Nájera quedó encuadrada en los dominios de Alfonso el Batallador. Poco después de morir éste, en 1134, retornaba a Castilla. Alfonso VII ratificaba en 1136 el fuero anterior. El Fuero de Nájera refleja de algún modo la realidad de ese período 1076-1136 en que la urbe, con independencia de vaivenes políticos, fue una localidad próspera, en crecimiento demográfico, con iglesias, gran abadía suburbana, barrios comerciales, mercados y una población en la que el componente de burgenses no era en absoluto extraño.

El propio léxico social del fuero, al tiempo que alerta sobre una posible hibridación textual, es reflejo de la heterogeneidad poblacional de Nájera. En ese sentido, además de albergar una comunidad judía y una comunidad clerical considerable, se perciben varias contraposiciones de categorías sociales: infanzones y villani, que son los dos típicos estratos de las comunidades rurales altomedievales; infanzones y vecinos o bien infanzones y plebs; asimismo infanzones y burgenses. Los infanzones son identificados con los propietarios de heredades y su asociación con el exitus indica el carácter arraigado y autóctono de esta baja aristocracia rural: "inffançones de Nagera qui sunt hereditarii in Nagera debent accipere in exitus tantum unus inffancion quantum duo burgenses, et debent isti inffançones ponere unum militem qui teneat annupdam ubi homines de Nagera necesse habuerint cum caballo et omnibus armis ligneis et ferreis, dice una de las cláusulas ${ }^{73}$. Otra cláusula equipara en la ciudad en algunos aspectos a los infanzones y los burgenses ${ }^{74}$, índice sin duda de las franquicias urbanas.

73. Fuero de Nájera §55. Recordemos que un documento leonés de 1093 (pero semejante sería para Castilla) definía quiénes eran los infanzones: "milites non infimis parentibus ortos, sed nobiles genere necnon et potestate, qui uulgari lingua infazones dicuntur", Colección Documental del Archivo Catedral de León. IV , ed. J.M. Ruiz Asencio, León, 1990, doc. n 1279.

74. Fuero de Nájera §54. Son otros muchos los parágrafos que contienen las típicas franquicias, sobre todo algunos muy sintomáticos del derecho de francos, como la prescripción de "año y día", Ibid., § 70; la inviolabilidad domiciliaria, Ibid., § 68; o la de la libertad de hacer transacciones y comerciar, Ibid., § 39, 40. Además, Ibid., § 18 a 24, 27, 51 a 53, 57, 59, 69. No entramos aquí en el contenido jurídico del llamado derecho de francos, que ha sido bien caracterizado por los juristas. Sobre todo se ha analizado en relación con el Fuero de Logroño, que es la fuente clave sobre ello. Vid. entre otros PELÁEZ, M. J., "Notas y precisiones sobre las 
El régimen de autoridades que se mencionan en el Fuero de Nájera no es muy explícito y no se concreta el grado de autonomía municipal: se menciona el palatium regis ${ }^{75}$ y el tenente, Ilamado dominator terrae, una autoridad de la tenencia que, como sabemos, se mantiene bajo el régimen concejil, mientras el iudex, que actuaría como delegado del dominator o vicarius regis, no parece una autoridad transferida al concilium, sino la clásica autoridad de la tenencia, probablemente bajo las órdenes del dominator ${ }^{76}$. No sabemos qué funciones se habían transferido al concejo urbano y si el texto foral refleja una instantánea o normas solapadas de varias épocas. Algunas de las alusiones que encontramos no ya en el fuero, sino en los documentos de la época, a "totum concilium de Naiara" no son las más significativas de la soberanía concejil, ya que son menciones que se encuentran también al margen de esta realidad ${ }^{77}$. Más concretas son las menciones a autoridades concejiles tanto en el fuero como en la documentación, en especial los alcaldes. El fuero parece indicar que alcaldes y sayones respondían a los intereses concejiles y tenían atribuciones judiciales, aunque fueran de índole menor y de derecho civil ${ }^{78}$. En el caso de los sayones la letra del fuero no da lugar a dudas sobre su designación concejil: "concilium de Nagera debent dare pro fuero duos saiones unoquoque anno ${ }^{1179}$. Los alcaldes de Nájera son citados también en documentación de la época: en 1121 -Miguel y Sancho Galindo-, 1124 y $1140^{80}$, entre otros.

En los siglos XI y XII, en pleno crecimiento de la urbe ${ }^{81}$, encontramos otro indicio de la organización urbana en la mención al concilium de los habitantes de los barrios de la ciudad. En documentos de 1056, 1060, 1067, 1068, 1078, 1085 o 1086 -por citar sólo años próximos a la época del fuero de Alfonso VI-

posibles raíces institucionales galas del Fuero de Logroño de 1095. El elemento franco de un texto iushistórico local", Berceo, 103, 1982, pp. 3-35. Asimismo RAMOS LOSCERTALES, J. Ma . "El derecho de los francos de Logroño en 1095", Berceo, 2, 1947, pp. 347-377. Interesan también algunos de los trabajos contenidos en El Fuero de Logroño y su época (Actas reunión científica, abril 1995, coord. J. García Turza), Logroño, Ayuntamiento, 1996.

75. Fuero de Nájera, §56, 86, entre otros.

76. Fuero de Nájera, § 8, 42.

77. Entre otras, en la documentación de Santa María de Nájera: 1085 (Santa Ma . Nájera, ed. M. Cantera, doc. 26), o 1151 (Ibid., doc. 57), entre otros.

78. Fuero de Nájera, § 70, 78.

79. Fuero de Nájera, § 77.

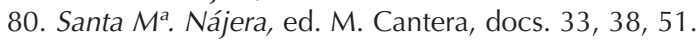

81. Nájera contaba entonces con varios barrios: San Miguel, San Esteban de Sopeña, Valcuerna, Tiendas, el barrio de los judíos, el del Mercado, el Puente, el de Santa María, el de San Juan, el de San Andrés; en la segunda mitad del siglo XII se menciona un arrabal o Barrio Nuevo. Vid. GARCIA TURZA, F. J., "Morfología de la ciudad de Nájera en la Edad Media", en III Semana de Estudios medievales (Nájera, 1992), Logroño, Instituto de Estudios Riojanos, 1993, pp. 63-88; ID., "Ciudades y aldeas: Nájera", cit.; PASSINI, J., "El Camino de Santiago en La Rioja: trazados y núcleos", IV Semana de Estudios Medievales (Nájera, 1993), Logroño, 1994, pp. 121-133. 
los habitantes de barrios concretos, formando un concilium de barrio -el de San Esteban, el de San Juan o Valcuerna- aparecen como testigos en diversas transacciones $^{82}$. No se trata de funciones políticas propias de autogobierno concejil, sino más bien de la aparición de la comunidad vecinal organizada, del mismo modo que el concilium rural emerge en la documentación de la época. Pero sí nos indica, si así queremos apreciarlo, que el tejido social y de participación comunitaria najerense presentaba una fisonomía típicamente urbana. Estos concilia autónomos de los barrios, propios de un tejido urbano formado por la amalgama de burgos, se acoplarán bien al sistema concejil urbano, tal como ocurre con otras ciudades del norte del Duero ${ }^{83}$. De algún modo, estas tempranas menciones najerenses representarían los prolegómenos de esas vías de acción comunitaria vecinal o concejos -entendidos como asambleas de vecinos- que se incorporarán al sistema concejil.

Por lo que respecta al requisito de la proyección espacial de la urbe, hay que decir que el "alfoz" de Nájera, con ese mismo nombre, es mencionado en el Fuero. La libertad de vendimia que se incluye en él es prueba de la personalidad reconocida a la comunidad local sobre la gestión de los bienes de ese término: "in quocumque loco inter terminos de alfoz homines de Nagera uineas habuerint, quandocumque uoluerint uindemient sine calumpnia et sine coto ${ }^{184}$, algo que parece extensivo al control del pastoreo en el término o vedado del concejo ${ }^{85}$. Pero la referencia del fuero que más podría sugerir que había algunas aldeas dependientes "del concejo" Nájera, y no ya sólo ubicadas "en" el alfoz regio de Nájera, por así decir, es la alusión a los lugares de Tricio, Aranzana, Huércanos, Azofra, Alexanco y Torrecilla "et de omnibus villis que ad Nageram pertinent ${ }^{1186}$. No se sabe a ciencia cierta a qué tipo de unidad espacial

82. "Concilio de Sancti Stephani", San Millán, 759-1076, ed. Ubieto, doc. 296, de 1059; "omne concilium de Sancto Stephano de Subpeña" [Sopeña], San Millán, 759-1076, ed. Ubieto, doc. 310, de 1060; "concilium de barrio Sancti lohannis", Valvanera, ed. García Turza, doc. 40, de 1067; "toto concilio de Sancti lohannes", Valvanera, ed. García Turza, doc. 47, de 1068; "toto concilio de Sancti lohannis de Valcorna", Valvanera, ed. García Turza, doc. 103, de 1078; ab omni concilio quod congregatur in eglesia Sancti lohannis Babtiste in varrio de Balcorna", Valvanera, ed. García Turza, doc. 185, de 1085; Ibid., doc. 186, de 1086.

83. En efecto, y a diferencia del papel totalmente unitario y envolvente del concilium general típico de los concejos de villa y tierra, en las ciudades y algunas villas del norte del Duero hemos sugerido que estas formas de sociabilidad política ligadas a los barrios y áreas topográficas de la ciudad, los concilia de los barrios, así como a sus diferentes componentes poblacionales -infanzones, castellanos o autóctonos, burgenses-, formaron parte identificable de los recursos de participación vecinal y de la composición sociopolítica de las ciudades. Lo hemos comprobado en Burgos, León, etc., como indicamos en "«Ayuntados a concejo». Acerca del componente comunitario en los poderes locales castellano-leoneses durante la Edad Media", en El poder a l'Edat Mitjana, Lleida, Pagès Editors, 2004, pp. 209-291, pp. 243-245.

84. Fuero de Nájera, § 48.

85. Ibid., § 88 .

86. Fuero de Nájera, § 75. 
se está refiriendo, pero podría ser un índice de proyección del concejo sobre aldeas próximas. Hay una mención a villas o lugares, así como a sus habitantes, que se hallan "sub imperio regis"

Se pueden detectar espacios de influencia más amplios que el propio alfoz concejil. La referencia al medianedo, que se detalla en el Fuero ${ }^{88}$, así como la mención a un amplio espacio -que llegaba al norte hasta el Ebro y al sur hasta más allá de Anguiano ${ }^{89}$-, en el que los habitantes de Nájera estaban exentos de montazgo y herbazgo, indica una proyección de la villa más allá de su propio término y posible alfoz concejil ${ }^{90}$.

Presumiblemente, el ramillete de aldeas que se citaban en el fuero, ese "alfoz" de Nájera, se mantuvo, aunque no conocemos la posible geografía exacta del mismo. De las aldeas mencionadas en el fuero, es posible que la de Torrecilla acabase con el tiempo pasando a señorío ${ }^{91}$. Pienso que el territorio concejil de Nájera no pudo extenderse porque estaba prácticamente rodeado por aldeas y partes de aldeas ya enajenadas, sobre todo en favor de Santa María de Nájera o San Millán de la Cogolla. Esto pudo dificultar la expansión².

El caso de Nájera, que acabamos de ver, representa en definitiva la combinación de dos grandes estímulos en la génesis del sistema concejil en la zona: el haber sido centro territorial regio y la existencia de población comercial o de

87. Fuero de Nájera, §50. Esto último no contradice la foralidad concejil, toda vez que la transferencia de dominio que los reyes hacían a los concejos no significaba la supresión del dominio y la jurisdicción realengas, sino sólo de su aplicación directa; además, quedaban vasallos y lugares no transferidos sino bajo control directo de los oficiales del monarca y su tenencia.

88. Fuero de Nájera, § 67.

89. Ibid., § 62, 63, 64 .

90. No obstante, tenía limitaciones, como por ejemplo que el radio de pastoreo reconocido no evitaba que el ganado tuviese que regresar a dichos términos por la noche: "Et si ganatum de Nagera exierit pasturare de istos terminos supraescriptos antea [límite norte: San Martín de Zaharra y el Ebro, límite sur: Santa Apolonia] tantum vadat quod per noctem possit reuerti infra terminos supraescriptos", Ibid., § 63. La existencia de un radio de influencia superior a la propia Nájera, con esa amplitud de las exenciones de herbazgo citado y radio del medianedo, ha sido expuesta en algunos trabajos de medievalistas especialistas en la zona. Vid. GARCíA DE CORTÁZAR, J. A., "La organización social del espacio en la Rioja cristiana en los siglos X y XI", cit., p. 160; PEÑA BOCOS, E., ÁLVAREZ LLOPIS, E., "El territorio y el Reino de Nájera en la Alta Edad Media", en B. Arízaga y J.A. Solórzano (eds.), El espacio urbano en la Europa medieval (Nájera, Encuentros Internacionales, 2005), Logroño, IER, 2006, pp. 541-587, págs. 583-585.

91. Lo indica GARCIA TURZA, F. J., "Ciudades y aldeas: Nájera", cit., p. 247. Y hay evidencias de que así fue, ya que un documento de Santa María de Nájera de 1215 (Santa Ma. Nájera, ed. M. Cantera, doc. 114) señala que la viuda de Diego López de Haro donaba dicha villa al monasterio.

92. Vid. supra, nota 65. También sobre estas cuestiones, con la interesante prolongación hacia la Baja Edad Media, puede verse el interesante trabajo de GOICOLEA JULIÁN, F. J., "La expansión territorial de los núcleos urbanos y la articulación de las relaciones con sus aldeas en la Rioja Alta medieval", AEM, n 32, 2002, pp. 293-331. 
burgenses capaz de generar tejido urbano genuino. El primero de los estímulos bastaría para propiciar la aparición de un sistema concejil. Sabemos que en áreas burgalesas ya desde el reinado de Alfonso VII sitios como Pancorbo, Briviesca, Villadiego, Palenzuela, Lara o Lerma, entre otros, comenzaron a desarrollar requisitos del sistema concejil, según nuestra interpretación, y por los datos existentes, no tanto empujados por su sociedad y economía urbanas sino tan sólo por la condición de cabezas de alfoz regio. Era una vía que hemos singularizado entre las que dieron lugar a sistemas concejiles ${ }^{93}$. Nájera la comparte, como decimos, pero tiene también el ingrediente de su desarrollo urbano como factor destacado.

No sabemos si en la zona de estudio despegaron algunos otros núcleos en el reinado de Alfonso VII, que fue fructífero en la vecina zona burgalesa. Los resultados, por los vestigios que han quedado en la documentación, parecen modestos. Núcleos de la zona de Tobía, Matute, Anguiano y Villanueva no parecen haber despegado como sistemas concejiles por entonces. La concesión en $1149^{94}$ de un pequeño régimen foral donde Alfonso VII concedía a los de Villanueva los mismos foros et consuetudines que tenían los de la vecina Matute, dista de tener un contenido municipal y más bien se inscribe en una modesta unificación de prestaciones y comunidad de pastos, acorde con la vida consuetudinaria de ambos lugares. Y habría que incluir quizás el caso de Villafranca, cuya fundación como villa y primeros tiempos históricos son desconocidos. De todos modos, hay que decir que el viejo emplazamiento de Oca, desde el traslado de la sede episcopal a Burgos en 1075, entró en declive pero la villa renovada de Villafranca, en un tramo del Camino claramente articulado por Belorado y Burgos, no se acabó convirtiendo en un enclave con gran futuro urbano.

Sin duda, hubo otra vía más potente y que es más característica de la Rioja que la que deriva directamente de la reconversión de los castillos regios en sistemas concejiles. Y es la creación de estos últimos a partir del estímulos como el Camino de Santiago, la vida urbana, la influencia del derecho de francos y, sobre todo, el deseo deliberado de la autoridad real de fundar una villa nueva o puebla nueva en un lugar escogido cuidadosamente y puesto en marcha con el objeto de recibir población, disponer de un mercado comarcal y reforzar los intereses regios en una determinada zona. El grado de autogobierno y de privilegios, sobre todo grandes exenciones y franquicias, fue en estos casos muy alto. En esta vía no importaba tanto si el lugar escogido tenía o no la condición de centro territorial. Esto último favorecía, naturalmente, pero no era imprescindible. En la secuencia histórica de esta vía de acceso al sistema concejil Nájera, a la que nos hemos referido, puede considerarse también precursora, por la

93. Vid. "Los territorios de las villas reales", cit., págs. 30-41.

94. Valvanera, ed. García Turza, doc. 220. 
doble condición de ciudad de burgenses y de centro territorial, como decíamos, pero sobre todo la madurez de dicha vía tuvo lugar con Alfonso VIII.

Lo veremos inmediatamente. Pero sin olvidar que otro gran precedente de villa del Camino, sin apenas pasado territorial regio, se dio antes, bajo el reinado de Alfonso el Batallador, en la época en que la zona de estudio, incluyendo la Rioja burgalesa, estaba bajo su control. En 1116 el monarca aragonés, el mismo que impulsaba también el modelo de repoblación concejil en tierras de frontera del Duero, otorgaba un fuero a Belorado ${ }^{95}$. Es seguro que a la población tradicional o rural de infanzones y villani la localidad sumaba ciertos contingentes de burgenses, probablemente una parte incluso de origen lejano. Otorgaba a los «francos» el máximo grado de autogobierno; y a la población autóctona o «castellanos» la posibilidad de elegir también a sus oficiales, si bien en este caso dentro de los hombres del rey. Esto revela que cada comunidad o grupo de origen tenía su régimen. Pero la territorialidad, tan característica del derecho municipal, irrumpía por encima al establecerse que ambos grupos "in unum" pondrían alcaldes unitarios: "Et vos, francos, mittatis iudice franco, atque tollite ad vestrum talentum; et castellanos similiter tollite, et mittite vestro iudice a vestro talento de mea gente; et omnes in unum mittatis alcaldes ad discurremdum iuditium $^{196}$. Entendemos que ambos grupos, pese a ver respetada su idiosincrasia, quedaban encuadrados políticamente en un solo concilium de la villa. El autogobierno concedido es cuarenta y un años anterior al que se halla en el Fuero de Logroño mejorado, lo que convierte a Belorado en una villa pionera de Castilla. El fuero destaca por otras cláusulas importantes, entre las que cabe mencionar la creación de un mercado semanal y una feria anual ${ }^{97}$, así como las típicas cláusulas de enfranquecimiento ${ }^{98}$, en la línea del fuero logroñés y francés. La creación del mercado de los lunes y el estímulo para que la villa se pueble -"qui venerit popolare in Bilforad, sua hereditate soluta habeat in tota mea terra" ${ }^{\prime \prime 99}$ - dan idea del propósito del fuero.

Pero, ¿por qué Belorado? Hasta el siglo XI no había sido un centro territorial. Es posible que adquiriera relevancia a finales del mismo. Lo cierto es que para Alfonso el Batallador era un sitio importante, sin duda por su situación geográfica, etapa jacobea a medio camino entre Nájera y Burgos -capitales de reinos ambas-, y a caballo entre las áreas de cultivo de las Ilanuras cerealistas o vitícolas de Bureba-Ebro y las de la Sierra de la Demanda, de aprovechamientos pecuarios y forestales. Para el monarca aragonés, que controlaba entonces la

95. Fuero de Belorado, en Fueros locales en el territorio de la provincia de Burgos, ed. Martínez Díez, Burgos, 1982, doc. 9.

96. Ibid., § 19 .

97. Ibid., § 8 .

98. Ibid., § 1,2, 3,5, 13, 20, entre otros.

99. Ibid., § 9 . 
región, Belorado habría sido, probablemente, referencia clave. Y lo prueba el hecho de que es uno de esos nombres de territorios de primer orden que se mencionan entre los gobernados por el monarca. Como dice el propio fuero "regnante rex Aldefonsus in Aragonia, et Pampilona, in Naxera, in Cereso, et Bilforad, in Carrion, in Sancti Facundi, et in Toleto... ${ }^{1100}$. Presumiblemente, Belorado iría desplazando a Pedroso, la vieja cabeza del alfoz regio. Con el tiempo la tenencia de Pedroso iría degradándose y la capital de la comarca acabaría siendo Belorado, que además fue donde se ubicó la nueva tenencia regia ${ }^{101}$. Otra cuestión es que esta villa, como tantas otras de la zona norte del Duero, no pudo incorporar con el tiempo más que unas pocas aldeas. En el fuero se cita un término donde aparecen dos aldeas a unos kms. de la villa -Terrazas y Villaipún, cerca de la actual Castildelgado, -, pero es dudosa la redacción en la época ${ }^{102}$. Sí parece síntoma de la influencia espacial la mención a un medianedo o gran término judicial que se extendería desde Belorado hasta Montes de Oca y Nájera ${ }^{103}$.

De modo que, aunque a una escala muy baja, puede decirse que la villa se convirtió en cabecera concejil sobre aldeas próximas. Indagando en datos posteriores de los siglos XII y XIII hemos sugerido que, además de aldeas suyas propiamente, sobre todo la villa misma de Belorado funcionó como un polo de atracción de pobladores de la zona. En un documento de San Millán de 1139 se menciona el caso de hombres que tenían posesiones del monasterio en lugares próximos a la villa -Terrazas, Sagrero, Redecilla del Camino y Rehoyo- y que habían acudido a poblar la villa, "hominibus illarum villarum qui morantur in Bilforado ${ }^{1104}$. Otro documento de 1187 permite saber que se estaba poblando en la villa un "barrio novo", al que seguirían acudiendo gentes del entorno ${ }^{105}$.

100. Este tipo de menciones se hallan también en otros documentos de este reinado: $C D M$ Rioja, ed. Rodríguez de Lama, docs. 94, 102, 105, entre otros. En uno de los diplomas, concretamente de 1129, se decía que el rey lo era "de Barbastro usque Uilliforato", Ibid., doc. 97.

101. Vid. nota anterior. En 1128 Alfonso el Batallador tenía a Gasión al frente de la misma, CDM Rioja, ed. Rodríguez de Lama, doc. 93.

102. Sobre todo porque se citan también "Otercorvo" y "Villafranca", algo poco verosímil: "et suum exidum habeat Bilforad de Oter Corvo usque ad Terrazas, et de Villa de Pum usque ad Villafranca", Fuero de Belorado, § 4. La escasa documentación conservada es, desgraciadamente, bastante posterior a la época que aquí interesa. Puede encontrarse para épocas posteriores en BLANCO, F., "Catalogación de documentos medievales de la Rioja Burgalesa", Boletín de la Institución Fernán González, 1970-73, nº, 175, pp. 385-403, n 176, pp. 602-618, nº 177 , pp. 730-745, no 178, pp. 155-169, no 179, pp. 376-389, n 180, pp. 691-708.

103. Ibid., § 20. No obstante, como hemos señalado precisamente a propósito de Belorado, este ámbito del medianedo no puede identificarse con el alfoz concejil de la villa, "La formación del sistema concejil en la zona de Burgos", p. 146.

104. San Millán, 1076-1200, ed. Mª. L. Ledesma doc. 374. En el diploma Alfonso VII reconocía que el monasterio tenía derecho a percibir sus tributos. Pero el documento interesa aquí como indicio de un flujo migratorio a la villa.

105. San Millán, 1076-1200, ed. Ma. L. Ledesma doc. 455. 
El concejo de Belorado, aunque ya con adquisiciones posteriores ${ }^{106}$, logró ampliar su área de influencia, si bien mínimamente.

Para la zona de estudio, como decíamos, fue decisivo el reinado de Alfonso VIII. Este monarca no se conformó con reconvertir las tenencias tradicionales, algo que resultaba a veces imposible al carecer éstas a menudo de un hinterland de realengo viable. Fue más ambicioso: por lo pronto, cuando llegó al trono se encontró ya con una cláusula de mejora del fuero de Logroño, dada por Sancho III de Castilla en 1157, que sin duda corregía el déficit de autogobierno del primer texto logroñés ${ }^{107}$; pero además convirtió este texto mejorado en el gran instrumento jurídico de la monarquía castellana para llevar a cabo un gran programa de fundación de villas nuevas, que sin duda cumplían todos los requisitos de lo que entendemos por sistema concejil. Alfonso VIII pensó en reforzar el realengo en un eje norte-sur de villas desde la Castilla septentrional hasta el Cantábrico, al tiempo que desarrollar las villas costeras de éste, pensó reforzar asimismo los tradicionales ejes este-oeste, del Camino pero también la línea del Ebro, y creyó conveniente en cualquier caso agrupar el realengo de aquellas comarcas donde esto era posible en torno a nuevas villas. Castro Urdiales, Santander Laredo, San Vicente de la Barquera, Frías, Miranda, Medina de Pomar, entre otras, fueron fundaciones suyas. He señalado en otras ocasiones que este tipo de fundaciones me parece diferente a la tradicional reconversión de las tenencias o alfoces. De hecho, varias villas nuevas de esta época no habían sido con anterioridad capitales de las tenencias ni tenían rango castral. Y por otra parte los ingredientes de tipo económico, las rutas comerciales ${ }^{108}$, unas sociedades con fuerte carga burguesa o la preocupación por asegurar las fronteras con Navarra mediante áreas nuevas avillazgadas fueron fundamentales en estas fundaciones $^{109}$. La zona de estudio, que ya contaba previamente con Nájera y

106. Vid. supra.

107. La adición de Sancho III dice: "Ego Sancius rex, filius imperator (...) dono et concedo ad bonos homines de Logronio foro, quod semel in anno mittent archalt (=alcalde) per sua manu et manu seniore qui dominauerit illa uilla". Recordemos que en el Fuero de Logroño de 1095 alcaldes, merino y sayones eran escogidos por el senior. ("Fueros de la Rioja", ed. Martínez Díez, doc. 10, Fuero de Logroño, § 25). Cito por la edición más reciente (las anteriores a cargo de J. González, Martínez Díez y A. Ma . Borrero) del fuero, ofrecida hace unos años por F. J. GARCÍA TURZA, "El Fuero de Logroño. Transcripción", en El Fuero de Laredo en el Octavo Centenario de su Concesión (ed. J. Baró, M. Serna), Santander, 2001. pp. 21-30.

108. No incido mucho en esta cuestión aquí, pero es evidente que el monarca apoya el comercio también con otras medidas. Las exenciones de portazgo, por ejemplo, eran una de las vías. Nos hemos referido antes al concejo de Nájera. Pues bien, en 1174 Alfonso VIII otorgaba dos privilegios a los vecinos con la exención de portazgo en Burgos y toda Castilla, al norte del Duero, y por otra parte en Soria y en toda Extremadura. Lo menciona MOYA VALGAÑÓN, J.G., "Documentos medievales del Archivo Municipal de Nájera", Cuadernos de Investigación, t. 7, fasc. 1-2, 1981, pp. 55-72, docs. 1 y 2.

109. Me remito a las consideraciones que hago en "Los territorios de las villas reales", pp. 44-47. 
Belorado, fue con Villafranca, Haro, Ibrillos y Santo Domingo de la Calzada, una de las tres grandes subregiones priorizadas en esta estrategia del rey de concentrar en villas el realengo de que aún disponía, junto con las villas de la costa cantábrica y las situadas en la zona burgalesa al norte del Ebro.

El Fuero de Haro de 1187 es uno de los textos más importantes de este ciclo de fundaciones en la zona ${ }^{110}$. El autogobierno del fuero de Logroño mejorado se superaba ya abiertamente. La transaccionalidad que contenía el privilegio de Sancho III de Castilla desaparecía ya en Haro y en los otros fueros de Alfonso VIII. Aunque seguía existiendo el delegado regio o senior ${ }^{111}$, la autonomía concejil para poner alcaldes, así como otra oficialidad concejil, era ya plena. El Fuero de Haro muestra la transferencia de oficiales del rey al concejo, quien los elegiría cada año: "Et alcaldes et adelantado et saion non sint nisi per unum annum et per manum totius concilii constituti, et non aliter ${ }^{\prime 112}$. El concejo contaba incluso con una participación en las caloñas, repartidas por mitad entre el concilium y el poder regio ${ }^{113}$. El desafío judicial ${ }^{114}$, las diligencias hechas por el sayón del conce$\mathrm{jo}^{115}$, las penas por llevar armas que recaudaría el concejo ${ }^{116}$, entre otros, son indicios de la personalidad jurídica del concejo y sus oficiales. Los alcaldes municipales no sólo actuaban autónomamente respecto del senior sino que eran retribuidos con una participación en las caloñas: "et alcaldes decimas omnium calumniarum percipiant et nunquam in conspectu domini eo presente iudicent ${ }^{\prime \prime 1}{ }^{17}$.

El estatuto de las personas, de los habitantes de Haro, era ventajoso en relación con el régimen de áreas próximas, en muchos sentidos. Entre otras cosas, el acceso de los vecinos a sus bienes en todo el reino libremente ${ }^{118}$ o el privilegio de ser juzgados por el derecho municipal desarrollado en el fuero de Logroño, hacían óptimo el estatuto jurídico de los habitantes de la villa. La exención fiscal a quienes acudieran a poblar la villa, así como la exoneración de los lazos que pudiera tener fuera de ella, muestra claramente cuáles eran los objetivos de la creación de estas pueblas de Alfonso VIII, no sólo en Haro sino en todas ellas $^{119}$. Entre estos objetivos estaba también el de dar fluidez a los intercambios

110. Fuero de Haro, "Fueros de La Rioja", ed. Martínez Díez, doc. 20.

111. Cuando acudiera a la villa se le prestaría alojamiento y atención debida, pero no actuaría de forma arbitraria, sino por mediación del sayón -el sayón concejil-: "Quando dominus villae ad villam venerit non detur ei hospicium nisi pro manu saionis", Fuero de Haro, § 15.

112. Fuero de Haro, § 23.

113. Fuero de Haro, $\S 7$. Las collaciones de la villa eran las beneficiarias de los bienes de quienes no dejasen descendencia, Ibid., $\S 32$.

114. Fuero de Haro, $\$ 8$.

115. Ibid., § $24,26,31$.

116. Ibid., § 25 .

117. Ibid., $\$ 37$.

118. Ibid., § 39 .

119. "Et omnis homo qui cum pectero aliquo ad Farum populare venerit nihil pectet nullumque extra villam faciat forum", Fuero de Haro, § 11. 
comerciales entre los núcleos subregionales. El propio fuero de Haro lo demuestra al eximir de portazgo al habitante de Haro en los mercados de Burgos, Nájera y Logroño ${ }^{120}$.

La transferencia de dominio real al concejo de Haro es muy explícita y el Fuero se abre con ella. Con la excepción de la serna regis, una cláusula muy habitual en las dotaciones concejiles, y que a mi juicio representa una reserva de 'realengo directo' dentro del perímetro de la puebla, el monarca trasvasaba todo el dominio que al rey pertenecía en un área que comenzaba así a depender de la villa. Tanto que incluía en ella todo lo que el rey tenía en el alfoz de Bilibio-Haro y en los montes cercanos. Todo pasaba ahora al concejo de la villa, "vobis omnibus populatoribus de Faro tam presentibus quam futuris: dono et concedo omnem hereditatem regalem que est in alfoz de Bilibio et de Faro, exceptis sernis regis, cum omnibus montibus de Bilivio et de Faro pertinentibus et cum montibus et hereditate de Vallepierre ${ }^{I_{122}}$. Aunque es difícil saber si el realengo de Bilibio pasó a Miranda ${ }^{122} \mathrm{o}$ a Haro, como parece indicar la donación citada, todo indica que se produjo una absorción del área de la vieja tenencia por una u otra villa. En el caso de Haro, no obstante, el espacio concejil inicial debió ser modesto. La adquisición de aldeas por parte de Haro fue posterior, como luego se indicará. Hacia 1200, o poco después, el espacio de Haro no tenía lugares adscritos al sur del Tirón y, por el norte, alcanzaba hasta el monasterio de Santa María de Herrera, ubicado entre Miranda y Haro y que también recibió donaciones de Alfonso VIIII ${ }^{123}$. No sabemos exactamente la proporción y la secuencia histórica, pero suponemos que el realengo directo del alfoz de Bilibio acabó repartido entre la puebla de Miranda, la de Haro y el dominio del monasterio citado.

Hay más casos en la zona de estudio en los que fue decisivo el reinado de Alfonso VIII. Al igual que en otros concejos burgaleses ${ }^{124} y$ en el que acabamos

120. Ibid., § 13 .

121. Fuero de Haro, cit.

122. No olvidemos que en el Fuero de Miranda de Ebro se menciona el paso de los alfoces de Cellorigo y Bilibio a la villa burgalesa, Fueros locales en el territorio de la provincia de Burgos, ed. G. Martínez Díez, cit., doc. 23, § 5.

123. Alfonso VIII en 1203 dio al monasterio el dominio regio desde Bilibio hacia Miranda, pero ya en 1172 le había hecho beneficiario de otras concesiones, El Reino de Castilla en la época de Alfonso VIII, ed. J.González, Madrid, 1960, 3 vols., Col. Documental., docs. 171 y 740 . En 1237 se comprueba que el área de Haro limitaba con el dominio del monasterio, Reinado y diplomas de Fernando III (II y III, Documentación), ed. J. González, Córdoba, 1980-1986, 3 vols., Col. Documental, doc. 600. Vid. asimismo GOICOLEA JULIÁN, F. J., "Poblamiento y organización político administrativa de las comunidades medievales del término de Haro en los silos XXII", Berceo, 125, 1993, pp. 77-90; ID., "La expansión territorial", cit. Aunque trata del período bajomedieval, interesan también de este autor, máximo especialista en la villa medieval de Haro, algunas partes de su libro Haro: una villa riojana del linaje Velasco a fines del Medievo, Logroño, 1999.

124. Casos de Miranda de Ebro, Frías o Medina de Pomar, MONSALVO ANTÓN, J. Ma., "La formación del sistema concejil en la zona de Burgos", cit., pp. 166-167. 
de citar de Haro, en Ibrillos ${ }^{125}$ era reconocida la autonomía municipal: "Sayon per manum concilii sit et non nisi per annum et alcaldes et adelantados non sint nisi per unum annum, excepta voluntate conciliii"126. El Fuero de Ibrillos, de hacia 1199 y que sigue muy de cerca la letra del de Haro, permite comprobar también que el requisito del sistema concejil que identificamos como de absorción de funciones políticas, administrativas y de fiscalidad era igualmente reconocido: gestión de los bienes de los que muriesen sin descendencia por parte de las collaciones de la villa' ${ }^{127}$, responsabilidad del concilium en la fijación del desafío judicial y la regulación de los testimonios ${ }^{128}$, percepción de las caloñas y prendas por el sayón de concejo ${ }^{129}$, imposición de multas por parte del concejo, por llevar $\operatorname{armas}^{130}$ o por cometer fraudes en las medidas ${ }^{131}$. Se establecía un reparto de las caloñas a tres partes entre el tenente, o sea, el que tenía la tierra, el propio fisco regio y el concilium ${ }^{132}$.

El rey otorgaba también a los habitantes de Ibrillos ciertos términos. "Concedimus populationem", dice el protocolo del Fuero y luego añade que estos habitantes "habeant totam illam regalem hereditatem que antiquitus fuit de Ivriellos". Estas concesiones se completaban con la exención de montazgo en un radio que se extendía hasta Pancorbo, Piedralada y Montes de Oca.

Un caso excepcional de expansión de una villa de la zona en el reinado de Alfonso VIII fue el de Santo Domingo de la Calzada. Normalmente, el señorío eclesiástico fue refractario en el norte del Duero a la aparición de sistemas concejiles. Tan sólo si se trataba de un burgo con población artesanal y comercial o enclavado en una ruta especialmente favorecida, los requisitos asomaban, si bien muy tímidamente. Fueron los casos de Silos, Santander o Sahagún, por ejemplo. Y aun así, cuesta ver en tales núcleos bajo jurisdicción eclesiástica que se consumaran condiciones tales como la de vecindad plena y, sobre todo, un alfoz concejil claro, requisito muy difícil de obtener. Pienso que lo era fundamentalmente porque quebraba las concepciones dominiales tan cerradas propias del abadengo. De modo que los avances hacia el autogobierno y la vecindad concejil fueron característicos del realengo, como hemos visto en todas

125. Fueros locales en el territorio de la provincia de Burgos, ed. G. Martínez Díez, cit., doc. 28.

126. Fuero de Ibrillos, § 23. Hay otros parágrafos del fuero donde parece contraponerse un alcalde de rege al alcalde concejil; y además aparece mencionado como adelantado de concejo: "Tot alcalde de rege det iurador" (Fuero de Ibrillos, § 44); "Tot alcalde de Livriellos adelantado de conceio nada non pectet et non faga facendera" (Ibid., § 36); "Tot adelantado de conceio otorgado non pectet fossadera" (Ibid., § 45).

127. Fuero de Ibrillos, $\S 32$.

128. Ibid., $\$ 8,17$.

129. Ibid, § 26, 29, 31.

130. Ibid., § 24, 25.

131. Ibid., $\$ 18$.

132. Ibid., $\$ 7$. 
partes. Santo Domingo de la Calzada es, en este sentido, excepcional, porque un incipiente sistema concejil logró despegar bajo el régimen de burgo abacial con derecho de francos, si bien luego acabó siendo villa realenga.

El potencial de Santo Domingo había surgido tras la fundación por Domingo de la Calzada, que vivió hasta 1109 y que impulsó la atención a los peregrinos haciendo en la segunda mitad del siglo XI un puente sobre el Oja, para evitar el paso por un peligroso bosque en Ayuela. Cambió así el trazado de la ruta jacobea en la zona y ese fue el origen del burgo, que empezaría a prosperar seguramente en el reinado de Alfonso VI. Un burgo abacial al principio articulado por un hospital y una iglesia y que tuvo jurisdicción eclesiástica como colegiata desde mediados del siglo XII hasta 1232. Fue una comunidad de canónigos bajo un abad, compartiendo desde entonces la sede con Calahorra, diócesis a la que había sido adscrito el burgo en época de Alfonso VII. En todo el período de jurisdicción eclesiástica gozó de privilegios de los reyes, dentro de una política habitual seguida con otras entidades eclesiásticas a las que generosamente se quería robustecer con franquicias y privilegios de tránsito, como lo prueban privilegios de 1141 y $1187^{133}$. Pero lo sobresaliente de su encaje jurídico fue la concesión en 1207 de un fuero municipal basado en el de Logroño, en su versión ya por supuesto mejorada, texto al que el de la villa calceatense seguía casi literalmente ${ }^{134}$. La villa siguió dependiendo de la jurisdicción del abad y desde 1232 del cabildo catedral ${ }^{135}$ hasta su paso al realengo en $1250^{136}$. En todo este tiempo el desarrollo urbano y comercial convirtió a la villa en un importante enclave de la región ${ }^{137}$.

133. En 1141 Alfonso VII había concedido al burgo abacial el aprovechamiento de pastos comunes y montes con los lugares próximos; y en 1187 Alfonso VIII concedía exención de portazgo, pero no a los clérigos sino a los habitantes del burgo: que no pagasen portazgo en las villas y castillos de Villafranca, Belorado, Cerezo, Pancorbo, Grañón, Haro, Nájera y Logroño; por otra parte, les otorgaba derechos de pasto con los lugares próximos: valle de Ojacastro y aldeas próximas al burgo. Vid. Cartularios de Santo Domingo de la Calzada, ed. UBIETO ARTETA, A., Zaragoza, 1978 (=Sto. Domingo Calzada, ed. Ubieto), doc. 12; Colección Diplomática Calceatense. Archivo Municipal (1207-1498), ed. LOPEZ DE SILANES, C. SÁINZ RIPA, E., Logroño, 1985, 1989 (= Col. Diplo. Calceatense. Municipal, ed. López de Silanes y E. Saínz Ripa), apéndices I y II, pp. 234-235.

134. "Fueros de la Rioja", ed. G. Martínez Díez, doc. 19, texto segundo.

135. Pueden verse los documentos de esta institución en Colección Diplomática Calceatense. Archivo Catedral (1125-1397), ed. C. LÓPEZ DE SILANES, E. SAÍNZ RIPA, Logroño, 1985 (= Col. Diplo. Calceatense. Catedral, ed. López de Silanes).

136. Sto. Domingo Calzada, ed. Ubieto, doc. 142. Vid. infra.

137. Comenta algunas cuestiones de su desarrollo urbano MARTíNEZ SOPENA, P., "Santo Domingo de la Calzada", en VV.AA., New Medieval Towns of the South West with Regular Layout, part II. Spain (ed. CD-ROOM), pp. 263-268. El mismo autor traza ahí una interesante panorámica sobre la urbanización y el urbanismo de los siglos centrales de la Edad Media en el contexto de la Corona de Castilla, "Las tierras del rey de Castilla", Ibid., pp. 169-184. Con respecto al trazado y desarrollo urbanos de Santo Domingo de la Calzada, interesan además 
El reinado de Alfonso VIII había supuesto, como acabamos de ver, el triunfo de los sistemas concejiles en la zona, y en general en toda la Castilla septentrional. La fórmula se consolidaba pero tenía un techo, por así decir: en muchas comarcas no se podía intervenir porque ya no existía un realengo compacto, dada la fuerte enajenación previa. Pero además las pueblas creaban recelos en los señoríos. Alfonso VIII sospechó que una excesiva proliferación de villas nuevas podría molestar a los nobles y a la Iglesia, y ello pese a que les seguía concediendo lugares y derechos. La llamada Curia de Nájera, de hacia 1185, ponía trabas a los cambios dominiales entre tipos de señorío. Y expresamente el testamento del monarca de 1204 parecía sugerir que no se debían hacer pueblas nuevas si ello molestaba a los nobles y la Iglesia ${ }^{138}$. Seguramente, las viejas aristocracias laicas y eclesiásticas percibían la gran revolución espacial y política que suponían los sistemas concejiles, en la zona basados sobre todo en «villas nuevas».

Un régimen nuevo, aunque fuera elitista, reconocía por vez primera a los vecinos como sujeto jurídico y como nuevo poder. El sistema concejil como centro privilegiado de intercambios era capaz de poner en circulación en sus mercados diarios o semanales la riqueza creciente de la época, sobre todo al ser capaz de hacer surgir, en el caso de las villas nuevas, un eslabón intermedio y necesario entre la gran urbe y la modesta aldea, a menudo propensas a la incomunicación material. El concejo de la villa se había convertido también en competidor jurídico y de oportunidades que podía arrastrar población y hacer perder vasallos a los señores ${ }^{139}$. Y desde el punto de vista de la nueva territorialidad, y esto es algo que personalmente he enfatizado mucho, el sistema concejil significaba la aparición, yo diría casi por primera vez, de las "comarcas», entendidas como espacios congruentes. Antes había territorios regios, es cierto, pero las piezas elementales que incluían -las villas- carecían de cohesión entre ellas -sobre todo si no coincidían con un valle natural. Así siguió ocurriendo en los sitios no avillazgados. Pero desde que un concejo urbano, de ciudad o villa, tuvo su fuero, su derecho, sus autoridades propias, el citado mercado que la convertía en capital económica de su entorno, su personalidad como sistema concejil en definitiva, podemos decir que las aldeas ya no formaron asentamientos desagregados. Se convirtieron en parte de un todo, articulado, congruente, estructurado en torno a la ciudad o villa cabe-

PASSINI, J., Villes médiévales de Chemin de Saint Jacques de Compostelle (de Pampelune à Burgos). Villes de Fondation et villes d'origine romaine, Paris, 1984, la parte correspondiente; asimismo, AZOFRA, E., "Desarrollo urbano de Santo Domingo de la Calzada en los tiempos medievales. Nuevas aportaciones históricas", en III Semana de Estudios medievales (Nájera, 1992), Logroño, 1993, pp. 243-256.

138. Alfonso VIII, ed. J. González, doc. 769.

139. Más arriba citábamos el caso de cuatro aldeas de la comarca de Belorado cuyos habitantes, vasallos de San Millán, se habían ido a vivir a Belorado y no querían pagar tributos al monasterio. Vid. supra, nota 104. 
cera. Espacialmente, eso es una comarca viva. No lo habían sido en rigor los territorios regios. Sí lo fueron los espacios concejiles ${ }^{140}$.

El reinado de Alfonso VIII fue, seguramente y por todo ello, el más importante en la aparición de los sistemas concejiles de la zona. Pero el proceso no estaba entonces acabado. Durante el reinado de Fernando III se observa cierto estancamiento. Es una época en la que convive el respaldo regio a las villas ya consolidadas con los patrones tradicionales de relación de la monarquía con los nobles y los señores: el monarca siguió nutriendo los patrimonios señoriales -sobre todo eclesiásticos- a través de concesiones de aldeas, sobre todo en comarcas donde un avillazgamiento concejil espacialmente significativo ya no era posible, dada la desagregación del regalengum existente; y por otra parte, siguieron en pie las tenencias regias, pero ya en este período desprovistas de tanta carga administrativa como en el pasado. Un documento de Fernando III de 1237 permite comprobar ambas cosas a la vez, la concesión de aldeas regias a los señoríos eclesiásticos y la desnaturalización de los alfoces regios tradicionales, que seguía su curso. En ese año el rey confirmaba la donación de la aldea de Villasur de los Herreros al obispo de Burgos. Al otorgar la inmunidad se aprecia que en Villafranca, capital del territorio -no sabemos si el alfoz tradicional o ya un alfoz transferido a la villa- seguían existiendo un prestamero y un merino regios, encargados de la recaudación ${ }^{141}$. Es un simple ejemplo. Frente a estas dos fuerzas, todavía influyentes, es decir, la sangría de enajenaciones y las autoridades territoriales tradicionales, estas últimas en decadencia, los sistemas concejiles venían a ser en esa época los principales elementos de contrapeso. Eran garantía para los lugares del concejo villano de no pasar a señorío, como ocurría con otras villas del realengo directo, y eran al mismo tiempo la plasmación de la proyección de la villa sobre el entorno.

Siempre atendiendo a equilibrios entre el rey y las fuerzas del reino, observamos que incluso la jurisdicción eclesiástica podía retroceder ante el empuje concejil. En la zona de estudio el paso de Santo Domingo de la Calzada a realengo, en 1250, a realengo concejil claro está, se produjo con facilidad, con-

140. Esta idea de forja de «comarcas» o espacios supraaldeanos congruentes que aportó el sistema concejil la comentamos en el trabajo "De los alfoces regios al realengo concejl", cit págs. 82-86.; y, como argumento, constituye la tesis principal del reciente trabajo sobre la zona zamorana, donde intentamos demostrar que la nobleza señorial, pese a su poder y numerosas posesiones, no pudo tener en la zona espacios congruentes hasta que no vampirizó los que habían fraguado en los siglos XII y XIII gracias únicamente a los sistemas concejiles: "Espacios y territorios de la nobleza medieval en tierras zamoranas: de la «desagregación» a la «zonificación», de la «vieja» a la «nueva» nobleza", Actas del Segundo Congreso de Historia de Zamora, Zamora, 2007, t. II, pp. 133-171.

141. Fernando III, ed. J. González, doc. 585. Este merino era el tradicional o dominial, el merino del alfoz, como podríamos denominarlo, no una autoridad de rango superior, es decir, el titular de la merindad de Rioja, que por esa época estaría en pleno surgimiento. 
cediendo el monarca exenciones a la clerecía local, rentas y derechos diversos a cambio de que pasase al rey la jurisdicción de la villa, "señorío que solíades aver de la villa de Santo Domingo ${ }^{11 / 42}$.

Las pugnas con la nobleza marcaron, sin embargo, una parte del reinado de Fernando III y estos difíciles equilibrios quizá influyeron en la falta de ambición fundadora del rey en la zona, pese a que lo fundamental estaba ya hecho. En las relaciones con la nobleza, es sabido que el enfrentamiento entre Fernando III y Diego López III de Haro llevó al rey a ordenar la destrucción de varios castillos de esta familia. La localidad de uno de ellos, Briones, que hasta entonces no era nada relevante como vieja posesión de los señores de Vizcaya, acabará en el reinado siguiente convertida en una de las últimas villas de la zona. Pero hacia 1240 tan sólo era la sede del castillo de los Haro que el rey castellano hacía derribar, recuperando un dominio que poco después acabaría en fundación de nueva villa.

Precisamente fue en el reinado siguiente, con Alfonso $X$, cuando se produjo el último impulso de fundación de villas nuevas al norte del Duero. En la Castilla septentrional este rey se preocupó de crear una gran ruta jalonada de villas realengas con salida hacia el Cantábrico más oriental a través de tierras vascas, al tiempo que pretendió reforzar la frontera con Navarra de la mejor manera posible, es decir, fundando villas en el Ebro, en Álava y en Guipúzcoa, sin olvidar tampoco el propósito de corregir la dispersión de los pequeños asentamientos propios de estas tierras norteñas y su vulnerabilidad ante la nobleza local. La fundación de varias villas, entre ellas el citado Briones, en este último caso en la zona de estudio, muestran el proyecto regio, que también se extendió a otras regiones y que, además del propio impulso fundacional, incluía también la dotación de ferias, mercados, confirmación de franquicias y exención de portazgos ${ }^{143}$.

El fuero de Briones de $1256^{144}$, como los de esta época, seguía el de Vitoria -derivado a su vez del amejoramiento del de Logroño- y, como tal, incluía las típicas cláusulas de autogobierno ${ }^{145}$, pero en alguna de sus pequeñas variantes demuestra la sensibilidad regia para entender una problemática social que se

142. Sto. Domingo Calzada, ed. Ubieto, doc. 142. Igualmente en Col. Diplo. Calceatense. Catedral, ed. López de Silanes, doc. 30.

143. Hay que destacar la fundación en tierras alavesas de Treviño, Salvatierra, Santa Cruz de Campezo, Contrasta, Corres, Salinillas del Buradón y Arceniega; o en Guipúzcoa la fundación de Villafranca de Ordicia, Segura, Tolosa, Bergara y Mondragón; y Orduña en Vizcaya. En todos los casos se seguía el fuero de Vitoria, que se basaba en el de Logroño. En la Rioja, además de Briones, hay que destacar el impulso dado a Navarrete. Vid. el trabajo de CANTERA MONTENEGRO, E., "Franquicias regias a ciudades y villas riojanas en el marco de la política repobladora de Alfonso X", en VV.AA., Alfonso X el Sabio. Vida, obra y época. I (Actas del Congreso de la SEM, Madrid, 1989, pp. 79-93 (publicado también en Berceo, 114-115, 1988, pp. 105-118).

144. Fueros de La Rioja, ed. Martínez Díez, doc. 23.

145. Fuero de Briones, $\S 7$, entre otros. 
daba en algunos sitios: se trataba de atraer población a la villa, sí, pero permitiendo que no empeorasen privilegios o estatutos jurídicos personales en los casos de pobladores que eran dueños de solares $^{146}$ o divisas en lugares diversos, casi con seguridad personas de condición hidalga. Por ello, para no perjudicar los intereses materiales de estos pobladores rurales conspicuos, el fuero de Briones especificaba que "todos los fijosdalgo que poblaren en Briones que aquel fuero e aquellas costumbres e aquellos usos que avien cada uno en sus tierras que esos hayan en Briones", lo cual resulta tradicional en términos dominiales, pero eso sí, en una cláusula históricamente avanzada, añadía que "fueras ende que se judguen por el alcalde de la villa de Briones ${ }^{1 / 47}$. El usus terrae no podía prevalecer sobre la justicia concejil, naturalmente.

La villa de Briones fue una de las más modestas y en tratos como el anterior se nota esta prudencia en el trasvase del dominio. Su área de expansión fue, además, pequeña. Eso sí, mantuvo su condición de villa realenga, o como infantazgo, hasta la época Trastámara.

Mayor proyección tuvieron desde la época de Alfonso X en adelante, hasta el reinado de Alfonso XI aproximadamente, otras tres localidades que contaban con mayor potencial urbano en la zona, además de Nájera, cuyo ámbito concejil también sufrió algunos cambios ${ }^{148}$. Nos referimos concretamente a Santo Domingo de la Calzada, Belorado y Haro.

Santo Domingo de la Calzada incorporó Grañón. Aunque en el siglo XIV Grañón dejará de pertenecer a la villa -y acabó en los dominios de los Estúñiga-, lo cierto es que la localidad pasaba a ser aldea calceatense en 1256 . El

146. Hay que tener en cuenta que el contenido dominial que quedaba bajo control del sistema concejil y de los vecinos al norte del Duero no consistía en atribuciones unitarias de amplios espacios interaldeanos - como en los concejos del sur del Duero- sino en algunas villas integras, pero también en unidades más pequeñas, que alcanzaban el nivel de los solares -unidades de explotación y renta de tipo familiar- y las divisas -participación compartida de derechos y rentas en un lugar-; un documento muy interesante sobre la lucha de las villas y los señoríos por los solares y vasallos afecta a una zona no lejos de La Rioja: el pleito entre Oña y Frías. Nos referimos a este pleito, desde este punto de vista de lucha al nivel microeconómico precisamente, en "Los territorios de las villas reales", en concreto, págs. 63-70. Desde otra perspectiva de lucha judicial han comentado este pleito ALFONSO, I., JULAR, C., "Oña contra Frías o el pleito de los testigos. Una pesquisa en la Castilla del siglo XIII", Edad Media. Revista de Historia, $\mathrm{n}^{\circ} 3,2000$, pp. 61-88.

147. Fuero de Briones, $\S 37$.

148. En la segunda mitad del siglo XIV Nájera incorporó temporalmente Santa Coloma y Bezares, empeñadas por el prior de Santa María la Real. Pero Pedro I en 1362-1363 obligó al concejo de Nájera a devolverlas al monasterio, CANTERA MONTENEGRO, M., Santa María la Real de Nájera, siglos X-XIV, Madrid, 1987, t. III, docs. 312, 313, 314. Desde 1375 el concejo de Nájera extiende su influencia a Cenicero, previo acuerdo con los habitantes de esta localidad cercana, MOYA VALGAÑÓN, J. G., "Documentos medievales del Archivo Municipal de Nájera", cit., doc. 21. El autor reseña así el documento: "carta de compromiso entre el concejo y vecinos de Nájera y el concejo y vecinos de Cenicero por el que estos se hacen lugar de Nájera". 
declive como centro territorial regio se habría producido ya antes, puesto que en 1217 había sido enajenado ${ }^{149}$. El caso de Grañón no es sino una muestra más de esa gran tendencia que se detecta en los siglos XII y XIII: el cambio de territorialidad regia directa a la de las villas acabó arruinando muchas viejas tenencias próximas a estas últimas. La tenencia de Bilibio desapareció y la villa de Haro se convirtió en la nueva referencia de su área geográfica. Una parte de Bilibio quizá quedó engullida en Miranda, villa de Castilla Vieja que por otra parte fagocitó Cellorigo, otro viejo castillo tenencial regio. El auge de Belorado acabó hundiendo por su parte el papel del antiguo centro territorial de Pedroso. Tobía, Azofra, Cañas, Anguiano y otros castillos fueron abocados a la ruina histórica, y física a veces. Sólo sobrevivían cuando habían sido recicladas dentro de un sistema concejil: Villafranca, Cerezo, como también, en las vecinas tierras de la Bureba, ocurrió con Pancorbo o Briviesca... Las villas triunfaban, las tenencias se hundían. Ahora bien, esta selección, que no hacía más que empezar en el siglo XIII, apuntaba también en otra dirección, que no será significativa hasta la baja Edad Media: las grandes ciudades ascendían, las villas modestas -con poca población, ruralizadas, sin patriciado...- perdían influencia. Esta selección entre concejos no cuajó hasta la época de la monarquía centralizada, como hemos sostenido en algún trabajo ${ }^{150}$, pero ya se atisba en un hecho que afecta a la zona y todavía en pleno siglo XIII: la incorporación de Villafranca de Montes de Oca a Burgos, esto es, al señorío urbano de Burgos ${ }^{151}$.

Pero este ajuste en virtud del cual las villas medias y pequeñas sucumbían ante fuerzas mucho más poderosas, que aquí apuntamos ahora como algo incipiente, no era aún lo característico del reinado de Alfonso X. Todavía este monarca, como acabamos de apuntar, estaba fundando villas, en la zona -sería prácticamente la última iniciativa en ella ${ }^{152}$ y y fuera de ella. Por supuesto, no eran sólo fundaciones. También ferias, mercados y privilegios de diversa índole a las villas ya existentes.

149. G. MARTINEZ DIEZ, "Fueros de la Rioja", p. 372; I. RODRIGUEZ DE LAMA, Colección Diplomática Medieval de la Rioja, vol. III, Logroño, 1989, doc. 43; ibid., doc. 230.

150. "Centralización monárquica castellana y territorios concejiles: algunas hipótesis a partir de las ciudades medievales de la región castellano-leonesa", Anales de la Universidad de Alicante. Historia Medieval, no 13, 2000-2002, pp.157-202.

151. En 1255 Alfonso X concedía a la ciudad las villas de Lara, Barbadillo de Mercado, Villadiego, Belbimbre y la citada Villafranca, Colección Diplomática del Concejo de Burgos (8841369), ed. E. GONZALEZ DIEZ, Burgos, 1984, doc. 30. Vid. BONACHÍA HERNANDO, J.A., EI señorío de Burgos durante la Baja Edad Media (1255-1508), Valladolid, 1988.

152. El proceso de fundación de villas, con la creación de Briones, estaba prácticamente acabado en época de Alfonso X en la zona de estudio. Quizá, como ocurre en otras partes, los últimos peldaños en el proceso de génesis de los sistemas concejiles tuvieron lugar en áreas de montaña, en torno a algunos valles que quedaban sin organizar. El propio Alfonso $X$ ahondó en esta vía fundando villas en valles de algunas regiones septentrionales, como hemos indicado, pero en la merindad de Rioja no se documenta esta iniciativa. No obstante, debieron darse procesos similares en la Sierra de la Demanda, en esa época o después. De hecho, por el Ilamado fuero del Valle de Ojacastro de 1312 ("Fueros de La Rioja", ed. G. Martínez Díez, doc. 25) se 
En concreto, Santo Domingo, cuyo concejo estaba dirigido entonces por alcaldes y jurados anuales ${ }^{153}$, había recibido en 1260 privilegios fiscales ${ }^{154}$ y en 1270 se le dio un privilegio de aprovechamiento sobre aguas y pastos en lugares próximos, así como el reconocimiento de una feria anual, entre otras exenciones ${ }^{155}$.

El auge de Santo Domingo en el siglo que se extiende entre los reinados de Alfonso X y Alfonso $\mathrm{XI}^{156}$ se tradujo además en el hecho de haberse convertido en capital de la merindad menor de Rioja ${ }^{157}$. Pero se concreta también en otra situación característica: la adquisición de aldeas por el concejo. En un documento de

comprueba que el Valle formaba una unidad espacial compuesta por la villa de Ojacastro, que sería la capital, Ezcaray, Zorraquín y Valgañón. Podría parecerse a esos casos de sistemas concejiles de montaña nacidos tardíamente a partir del avillazgamiento concejil de un valle-como Valdeón, Laciana o Riaño en León, o como ocurrió en villas de Asturias o País Vasco en los siglos XIII y XIV-, aunque en el caso de Ojacastro no sabemos los jalones de dicho proceso de formación. La carta de 1312, a falta de otra fecha, sería la de referencia histórica y además aparece un claro propósito de fazer puebla: "por que mejor se pueble el dicho valle". El fuero garantizaba la protección a quienes, incluso delincuentes, se refugiaran en el valle, contenía una exención fiscal para los habitantes del mismo, incluyendo exención de portazgo, y les eximía de la jurisdicción y oficiales regios -merinos, sayones, etc.-, con lo que indirectamente se presupone que sus funciones quedaban en manos de las autoridades locales, aunque este extremo no se hacía explícito en la carta.

153. Así consta en un documento de 1264: "en cabo del año, quando los alcalles e los jurados conplieren su tienpo o ouieren de mudar alcalle e iurado para el otro año en adelante, que fagan ayuntar conçeio general de mayores e de menores e los alcalles e iurados que ffueren a la ssazón que escoian a los meiores omnes de la villa assi por alcalles commo por iurados", Col. Diplo. Calceatense. Municipal, ed. López de Silanes y E. Saínz Ripa, doc. 6.

154. De marzazga y yantar, Col. Diplo. Calceatense. Municipal, ed. López de Silanes y E. Saínz Ripa, doc. 3.

155. El privilegio lo confirmó Alfonso XI en 1332, Col. Diplo. Calceatense. Municipal, ed. López de Silanes y E. Saínz Ripa, docs. 7 y 8 . Esta política de privilegios y franquicias de Alfonso X en relación con la Rioja ha sido señalada por CANTERA MONTENEGRO, E., "Franquicias regias a ciudades y villas riojanas", cit. Vid. asimismo MARTíNEZ SOPENA, P., "Logroño y las villas riojanas entre los siglos XII y XIV", en Historia de la ciudad de Logroño. II. Edad Media (coord. J. A. Sesma), Logroño, 1995, pp. 279-322.

156. Sobre épocas posteriores a ésta, aunque aluden en algo también a ella, interesan algunos estudios: DIAGO HERNANDO, M., "Santo Domingo de la Calzada en la Baja Edad Media. Aspectos de su organización político-institucional", Berceo, 130, 1996, 107-122; y GOICOLEA JULIÁN, F. J.,"Sociedad y relaciones de poder en una ciudad riojana a fines del Medievo: Santo Domingo de la Calzada", Espacio, Tiempo y Forma. Serie III, Medieval, t. 12, 1999, pp. 243-286. De este mismo autor "Concejos urbanos en la Rioja Alta a fines del medievo: aspectos institucionales y políticos", HID, 26, 1999, pp. 233-253.

157. Según documento de Alfonso XI de 1326 en Santo Domingo había "mios alcalles que librasen los pleitos que les acaesçiesen e otossí meryno para conplir iusticia e las otras cosas que pertenesçen al ofiçio de la merindat", situación por la cual el monarca concedía que la autoridad territorial superior, la del Merino Mayor de Castilla, se inhibiese de actuar en la villa, cediendo tales competencias a esas autoridades de la merindad [menor] de Rioja. El privilegio, confirmado por reyes posteriores, en Col. Diplo. Calceatense. Municipal, ed. López de Silanes y E. Saínz Ripa, doc. 19. 
1260 se habla de "la villa con sus aldeas", pero no se tiene noticias de ninguna en concreto ${ }^{158}$, al margen del caso de Grañón, antes mencionado. Un trasiego competitivo y muy contingente entre el concejo y los señoríos e hidalgos de la zona con el fin de hacerse con solares y heredades, utilizando frecuentemente el expediente de las compras, debió marcar la historia del concejo calceatense en ese siglo. Las ventajas que ofrecía la villa permitían atraer población, pero el marco de dificultades materiales y el estatuto hidalgo de muchos habitantes complicaba el proceso. En $1314{ }^{159} \mathrm{Alfonso}$ XI debía corregir a la baja la estimación de cabezas de pecho de la villa, de 115 a 80 pecheros, no sabemos si como resultado de crisis socioeconómica o puramente demográfica. El concejo adquirió solares pero, por esta vía, por compra íntegra de una villa o por alguna otra vía, acabó teniendo aldeas enteras adscritas a su concejo. Sabemos que el control concejil de todos o la mayor parte de los solares de una aldea llevaba a disponer con el tiempo de la jurisdicción de la misma, si no se tenía de antemano, con independencia de que se respetasen los derechos dominiales de terceros. Todo indica que la vía de adquisición preferente fue adquirir los solares que tenían los hidalgos de la zona en varios lugares. Pino de Suso y de Yuso, así como Sonsoto, pertencían al alfoz concejil a mediados del XIV o quizá poco después, y Ayuela fue incorporada íntegra en 1352, mientras que con la adquisición de solares y divisas en Gallinero, Manzanares y Villalobar fue aumentando progresivamente la influencia dominial del concejo en ellas y, en el caso de la última, acabó en fecha tardía incorporada también al concejo de la villa ${ }^{160}$.

158. Col. Diplo. Calceatense. Municipal, ed. López de Silanes y E. Saínz Ripa, doc. 3.

159. Col. Diplo. Calceatense. Municipal, ed. López de Silanes y E. Saínz Ripa, doc. 16.

160. En los años 1261-62 el concejo compraba todo lo que Diego Íñiguez y Lope de Mendoza o su hermano tenían en Sonsoto, Col. Diplo. Calceatense. Municipal, ed. López de Silanes y E. Saínz Ripa, docs. 4 y 5. Lo adquirido incluía "collaços e ssolares e eredades, yermo e poblado". En 1282, incorporado ya todo lo de Diego Íñiguez en el lugar, Sonsoto pasaba al concejo de Santo Domingo, Ibid., Apéndice III, p. 235. En 1301 el concejo compraba heredades y viñas en Pino de Yuso, Ibid., Apéndice III, p. 236. En 1332 un matrimonio hidalgo de Gallinero (de Yuso) se avecindaba en Santo Domingo, traspasando su solar y vendiendo su divisa al concejo. La transacción consistía en ese caso en que el hidalgo, Martín Iñíguez, conservaría la propiedad del solar, pero no podría enajenarla a hidalgo ni a alguien ajeno al concejo, por lo que quedaba bajo éste, Col. Diplo. Calceatense. Municipal, ed. López de Silanes y E. Saínz Ripa, doc. 21. En 1333 el hidalgo Ruy Gil, y su sobrino, vendían un solar que tenían en Pino de Suso al concejo de Santo Domingo: "e este dicho ssolar uos vendemos a uos el dicho conçejo de Ssanto Domingo con ssu deuisa e con ffurçiones (...) e con entradas e con ssalidas (...) e partimos nos del sseñorío que en el dicho ssolar auemos o deuemos auer e traspassamos el dicho sseñorío enteramente en uos en dicho conceio", Ibid., doc. 23. En 1334 un matrimonio hidalgo empeñaba al concejo de Santo Domingo dos terceras partes de lo que tenían en Sonsoto, que incluía "palaçios e solares, poblados e por poblar, e vasallos e ffurciones e tributos, tierras e peças e heras e viñas e parrales e molinos e exidos e aruores e montes e pastos e prados e dehesas...", que prácticamente vendría a ser equivalente a la casi totalidad de la aldea: "e cotos e 


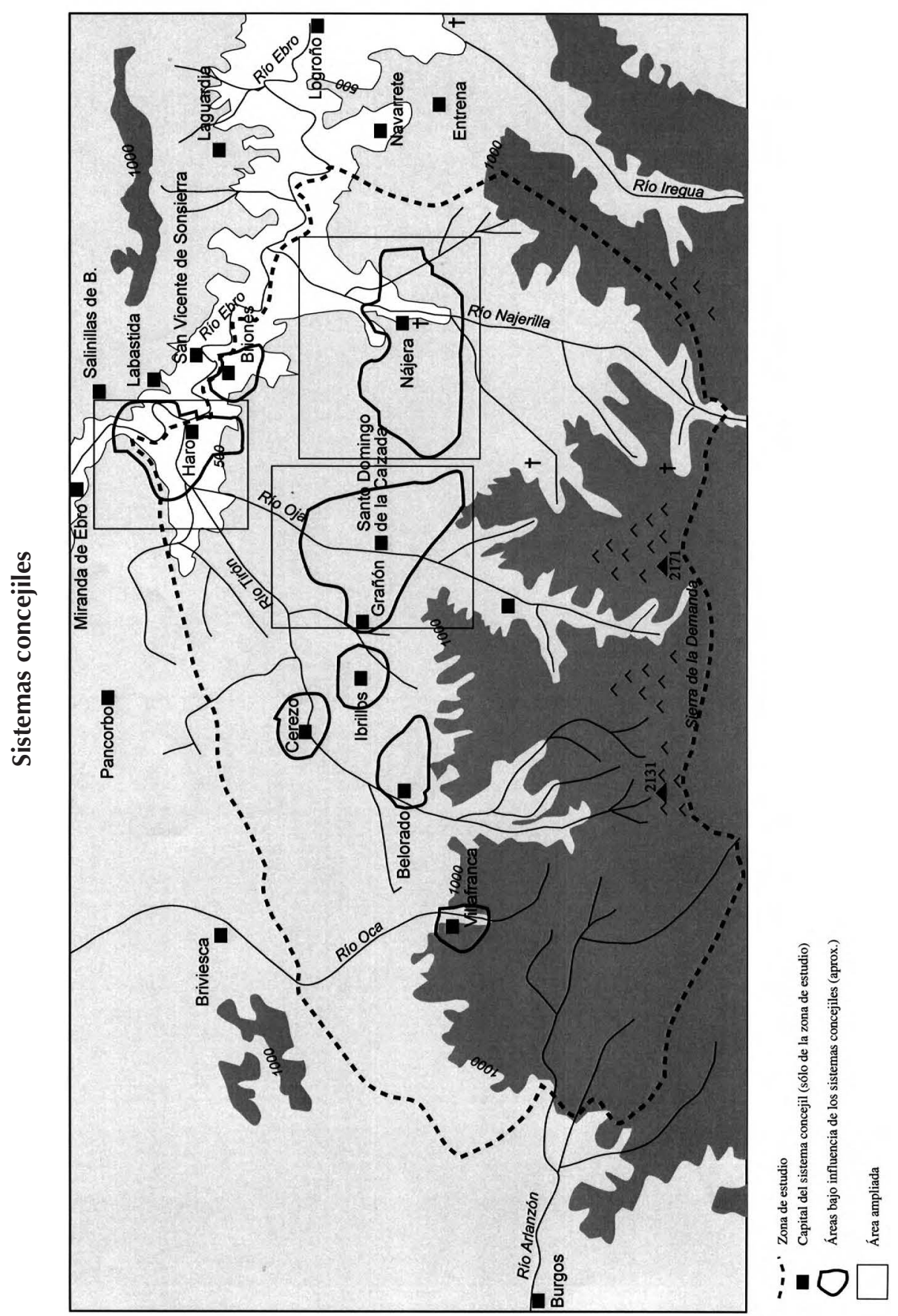




\section{Ámbito jurisdiccional de los concejos de villas y aldeas. Haro, Santo Domingo de la Calzada y Nájera en los siglos XIII-XV (límites aproximados)}

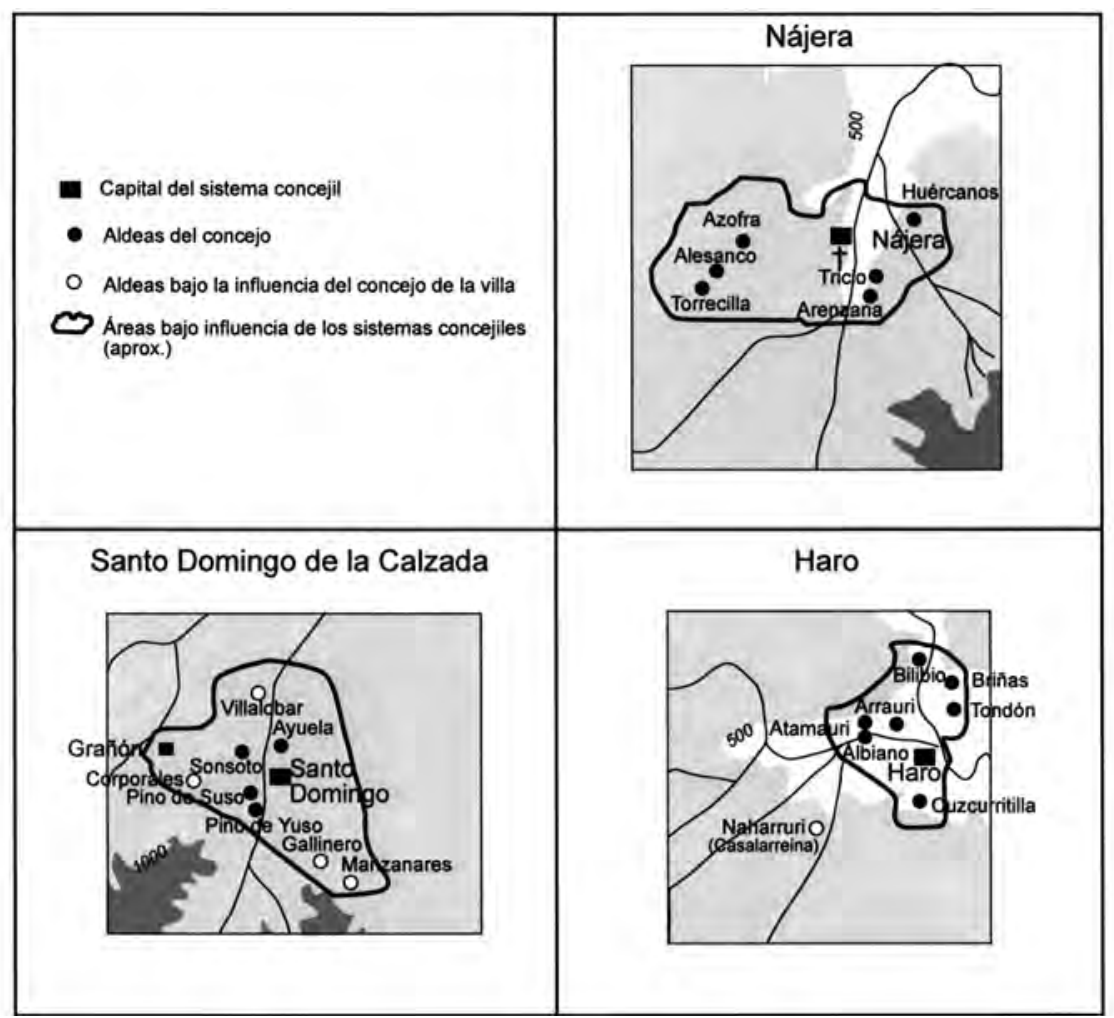

caloñas, omeziellos e deuisa e deuisas e sseñoríos", así como otros bienes que tenían en otros lugarejos (Velascor, Herramélluri y Bañares), todo ello empeñado por un plazo de 15 años por 10.000 mrs., Ibid., doc. 24. En 1340 Juan Ruiz vendía todo lo que tenía en Sonsoto, Villalobar, Gallinero y Pino, Ibid., Apéndice III, p. 236. En 1342 Martín Iñiguez y su mujer María Pérez vendían a Santo Domingo solar y derechos en Gallinero de Yuso, Ibid., Apéndice, p. 236. En ese año, pese a haber adquirido ya solares en los lugares, aún se decía que Pino de Yuso y Pino de Suso pertenecían a Juan Martínez de Leiva, Col. Diplo. Calceatense. Municipal, ed. López de Silanes y E. Saínz Ripa, doc. 29. En 1346, Fernando Ruiz vendía al concejo heredades que tenía en Manzanares, Gallinero y Pino de Suso, Ibid., Apéndice, p. 236. En 1347 Teresa Ruiz vendía al concejo lo que tenía en Corporales Ibid., Apéndice, p. 236. En 1349 Joaquín Ruiz vendía a la ciudad solares, heredades y pastos de Villalobar, Sonsoto, Pino de Suso, Gallinero de Suso y Gallinero de Yuso, Ibid., Apéndice, p. 236. En el caso de Ayuela se trató de una incorporación íntegra en 1352 cuando el monasterio de Santa María de Cañas, su titular, la donaba al concejo a cambio de un censo anual de 1.500 mrs., Col. Diplo. Calceatense. Municipal, ed. López de Silanes y E. Saínz Ripa, docs. 31, 32. En cuanto a Villalobar, entre 1380 y 1389 la ciudad compró a Sancha Ruiz de Rojas la aldea íntegra, Ibid., Apéndice III, p. 236. Y Pino de Suso, que no sabemos cuando se incorporó, es citado como perteneciente al concejo de Santo Domingo de la Calzada en un documento de 1392, Col. Diplo. Calceatense. Municipal, ed. López de Silanes y E. Saínz Ripa, doc. 39. 
Belorado también debió aglutinar un pequeño alfoz concejil en los siglos XIII y XIV. Alfonso X en 1256 y 1265 impulsó la repoblación de la villa, "por acrecentar vuestra villa et por levarla adelante et por facer la puebla que yo mandé facer", según dice el primero de estos documentos ${ }^{161}$. Pese a que las informaciones no son muy claras y son indirectas, es posible que las aldeas de Viloria de Rioja, San Pedro del Monte y San Cristóbal del Monte formaran parte de ese área concejil, aunque no es seguro que se mantuviera estable a largo plazo ${ }^{162}$.

Por lo que respecta a Haro, sin duda es otro de los casos en que el concejo de la villa consiguió incorporar también algunas aldeas a su alfoz concejil, formado por áreas del desintegrado alfoz regio de Bilibio y por otras aldeas próximas: compras en 1325 de las aldeas de Cuzcurritilla, Atamauri y Briñas, que culminarán con otras adquisiciones posteriores ${ }^{163}$.

Viendo el resultado final es evidente que los nuevos poderes concejiles habían cambiado profundamente la trama del poder y las jurisdicciones ${ }^{164}$. Hasta su aparición, el poder regio se ejercía sobre todo a través del dominio real o realengo, es decir el señorío que a los reyes les iba quedando una vez enajenados el dominio y la jurisdicción que iban concediendo a los señores. En los siglos X-XII este realengo, inexorablemente menguante, se gestionaba todavía de forma directa: los agentes del rey -seniores de los castillos, merinosrecaudaban para él los tributos de las aldeas de un determinado distrito y se responsabilizaban de la administración y la justicia en ellas.

Desde el momento en que comenzaron a surgir sistemas concejiles en el seno de ese realengo, se transfirieron funciones políticas a los concejos de algu-

161. En 1256 Alfonso X entregaba a los de Belorado el realengo periurbano que aún no había sido trasferido y señalaba que lo hacía con ese propósito repoblador, "Catalogación de documentos medievales de la Rioja Burgalesa", ed. F. Blanco, cit., BIFG, nº 177, p. 738; n 179, pp. 383-384.

162. En 1288 se decía que San Cristóbal del Monte era aldea de Belorado y, tras un paréntesis entre 1288 y 1295, a la villa siguió perteneciendo, "Catalogación de documentos medievales de la Rioja Burgalesa", ed. F. Blanco, BIFG, n 180, págs. 691-694; Viloria de Rioja y San Pedro del Monte se mencionan como aldeas de Belorado a principios del XV, Ibid., BIFG, no 178, p. 157.

163. La información sobre la adquisición de Cuzcurritilla, Briñas y Atamauri en 1325 procede del archivo municipal, y es Goicolea quien ofrece el dato. En 1407 Haro adquirió Naharruri (poco después Ilamada Casalarreina), aunque desde 1338 el concejo de Haro había adquirido propiedades allí, algo que también ocurría en la cercana Gimileo. Todo indica que los concejos de Briones y Haro se disputaron en el siglo XIV este lugar de Gimileo, con mayor éxito para aquéIla. Los datos sobre la ampliación del alfoz de Haro en GOICOLEA JULIÁN, F. J., La sociedad altoriojana a finales de la Edad Media: el ejemplo de la Villa de Haro y sus aldeas en el siglo XV (tesis doctoral inédita), pp. 118, 123; ID., "La expansión territorial", cit. pp. 301-303.

164. En algunos trabajos anteriores hemos desarrollado estas ideas sobre la evolución estructural de los concejos y la monarquía. Expongo aquí un esquema teórico más o menos adaptado o ejemplificado en la zona. Vid. el esquema. 
nas villas, conteniéndose el trasvase de lugares a los señores laicos y eclesiásticos. Al frente de los castillos siguió habiendo nobles en una relación con el rey de vasallaje y pecuniaria. Pero, como autoridades, fueron quedando solapados ya a las nuevas formas de poder, de modo que fueron los concejos de las villas quienes aplicaron cada vez más la justicia ordinaria, gestionaron los recursos de la Tierra -el alfoz concejil-, establecieron acuerdos con otros concejos, regularon el tránsito de mercancías, se responsabilizaron de la recaudación fiscal... Durante los siglos XII y XIII todo ello lo hicieron en nombre del rey, porque pertenecían al realengo, pero lo hicieron ya autónomamente, como «realengo transferido», que es como denominamos al sistema concejil visto desde el punto de vista de las escalas jurisdiccionales.

Para la monarquía esta transferencia no fue un inconveniente o una debilidad estructural, sino una sinergia, por tres fundamentales razones. Lo primero porque desde el siglo XIII la monarquía empezaba a desplegar unas funciones políticas superiores, por encima de las jurisdicciones señoriales concretas, incluida la propia, lo que permitió a los reyes no medirse con otros poderes señoriales, sino situarse en otro nivel superior: el "rey-rey" frente al "rey-señor", por decirlo vulgarmente. Este proceso de tránsito hacia la monarquía centralizada, que sustituyó a la monarquía feudal, sobra decir que fue mucho más eficaz a largo plazo, pues apoyó su supremacía en resortes imprescriptibles crecientes y universales sobre todo el conjunto del reino, lo que permitía a los reyes gobernar, legislar y recaudar sobre todos los súbditos y no sólo sobre los realengos. La segunda razón es que la fundación de sistemas concejiles desactivaba el poder espacial generado por los nobles a través de sus tenencias, que, aunque públicas, a nuestro entender eran fuente de sangría de dominios y de desgaste político de los reyes en escalas y territorios pequeños. En tercer lugar, por las ventajas intrínsecas de los nuevos poderes: porque los sistemas concejiles de las villas y ciudades fueron capaces de mejorar las economías de las comarcas e incluso de cohesionar éstas, algo que antes no se daba, ya que antes la relación entre castillo alfocero y aldea se expresaba de forma desagregada; y además porque los sistemas concejiles fueron capaces asimismo de servir de apoyos políticos solventes a una monarquía deseosa de asentar los nuevos aires de soberanía superior precisamente en capas sociales y centros de decisión colectiva que no fueran ya los tradicionales eclesiásticos y magnaticios, y en ese sentido las villas nuevas, con sus concejos urbanos, empezaron a ser un vector nuevo de relación política que antes no existía y que, por ejemplo, está en el origen de las reuniones de cortes.

En definitiva, apreciamos como los sistemas concejiles reflejan la realidad de un mundo urbano imparable, impulsado por el propio auge material de los siglos $\mathrm{XI}$ al XIII, como es bien sabido por la historia urbana y rural, pero que al mismo tiempo, como hemos querido mostrar aquí, venía sustentado por el empuje ascendente de una monarquía en trance de modernización centralizadora. 
JOSÉ M. ${ }^{a}$ MONSALVO ANTÓN

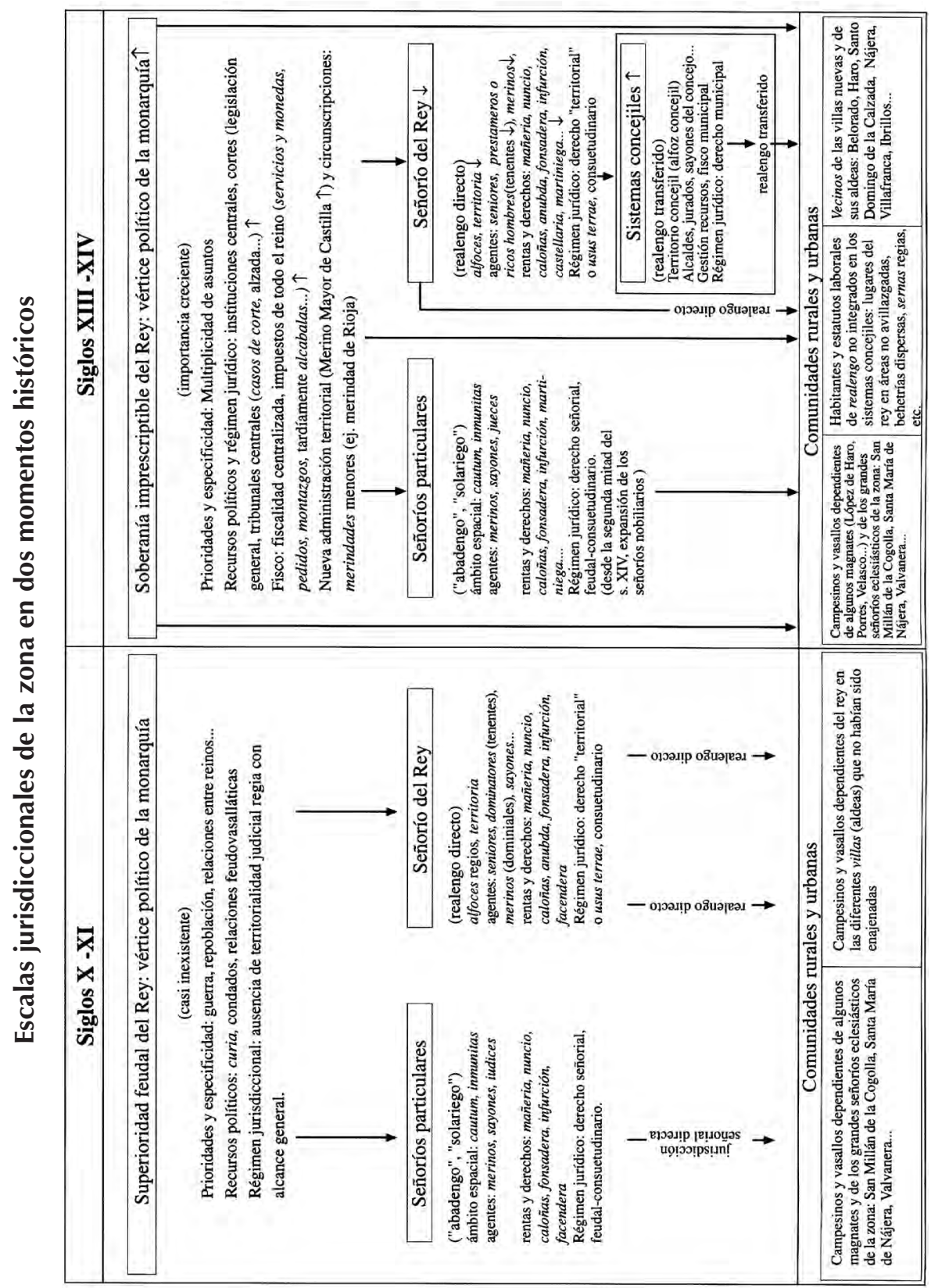

